\title{
Dlaczego w relacji Mateusza (21,1-11) Jezus wjeżdżał do Jerozolimy na dwóch osłach? Część 2: Motywy obecności dwojga zwierząt w tekście Mateusza
}

\author{
Why Did Jesus Enter Jerusalem Riding on Two Donkeys \\ in Matthew's Account (21:1-11)? \\ Part 2: Reasons for Having Two Animals in the Account
}

\author{
KS. ADAM KUBIŚ \\ Instytut Nauk Biblijnych, Katolicki Uniwersytet Lubelski Jana Pawła II \\ e-mail: akubis@gmail.com \\ ORCID: 0000-0003-4961-2254
}

\begin{abstract}
Summary: The article deals with one of the problematic issues found in the Matthean entry narrative (21:1-11), namely the reason(s) for introducing two animals into the account. The article provides an extensive discussion of the possible reasons for the biblical authors configuring the narrative in this way, presenting various allegorical, redactional, naturalistic, and intertextual interpretations. The article proposes that the most likely reason for introducing two animals into the narrative is simply to accurately reflect a real historical event - which in fact involved two donkeys. It is also argued that Matthew, as a theologian, was equally interested in demonstrating the fulfillment of Zec 9:9. Further, his narrative was also imbued with allusions to Mosaic as well as Davidic and Solomonic typologies.
\end{abstract}

Key words: Mt 21:1-11, donkey, Jesus' entry narrative, Zec 9:9, Mosaic typology, Davidic typology, Solomonic typology

\section{Wstęp: postawienie problemu}

М pierwszej części artykułu wskazaliśmy na argumenty za uznaniem dwojga zwierząt jako właściwego referenta ostatniego zaimka w Mt 21,7 $7^{1}$. Jezus, wjeżdżając do Jerozolimy, miał usiąść na dwojgu zwierzętach. Z problemem identyfikacji właściwego referenta dla drugiego zaimka $\alpha$ $\tau \tilde{\omega} v$ w Mt 21,7 łączy się jednak szersza kwestia motywu obecności dwóch osłów w Mateuszowym

1 A. Kubiś, „Dlaczego w relacji Mateusza (21,1-11) Jezus wjeżdżał do Jerozolimy na dwóch

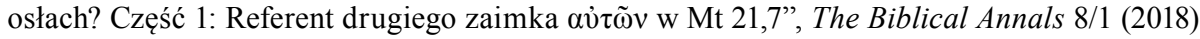
29-45. 
opisie triumfalnego wjazdu Jezusa do Jerozolimy (21,1-11). Jeśli bowiem uznamy, iż referentem problematycznego zaimka jest para zwierząt, rodzi się pytanie o motyw tak wielkiej Mateuszowej emfazy na temacie ich obecności. Dodajmy, iż paralelne narracje w trzech pozostałych Ewangeliach kanonicznych wspominają wyłącznie o jednym ośle. Nawet jeśli interpretatorzy opowiedzą się za

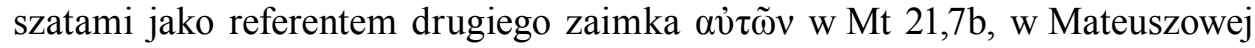
narracji obecne są nadal przynajmniej trzy niekwestionowane odniesienia do pary zwierząt $(21,2.3 .7 a)$. Wciąż zatem pozostaje intrygujące pytanie o motyw wprowadzenia do Mateuszowej narracji dwojga zwierząt. W niniejszym artykule skupimy się zatem na zdefiniowaniu motywów, dla których Mateusz przedstawił Jezusa jako siedzącego na dwojgu zwierzętach oraz kładł tak wielki nacisk na obecności dwojga zwierząt w narracji o triumfalnym wjeździe Jezusa do Jerozolimy. Przedstawimy wpierw interpretacje alegoryczne i odwołujące się do pracy redakcyjnej (jako najmniej przekonujące), aby przejść do rozwiązań bardziej sugestywnych: naturalistycznych i intertekstualnych.

Podobnie jak w pierwszej części artykułu, również tutaj w prezentacji powyższych zagadnień będą nam przyświecały te same dwa cele. Pierwszym jest wskazanie najbardziej przekonującego rozwiązania tytułowego problemu badawczego, uwiarygodnionego możliwie najbardziej wyczerpującą argumentacją. Drugi cel, historyczny ze swej natury, może być określony jako chęć prezentacji jak najszerszej gamy interpretacji powyższego problemu powstałych na przestrzeni wieków, a zatem nakreślenie wyczerpującego status quaestionis. Tytułowa trudność interpretacyjna została omówiona w języku polskim przez Romana Bartnickiego w artykule opublikowanym w 1976 r., w którym zaprezentował on także własne oryginalne rozwiązanie kluczowego problemu ${ }^{2}$. Niniejszy artykuł wypełnia jednak lukę w polskim piśmiennictwie biblijno-teologicznym, jaka powstała po publikacji R. Bartnickiego, prezentując i oceniając powstałe po 1976 r. rozwiązania trudności oraz zawierając pewne dopowiedzenia, których nie znajdziemy w publikacjach obcojęzycznych.

\section{Interpretacje alegoryczne}

Starożytni komentatorzy tekstu Mateusza utrzymywali, że ewangelista w sposób celowy mówi o nieprawdopodobnej rzeczywistości dosiadania przez Jezusa dwóch osiołków, gdyż zawiera w tym fakcie sens alegoryczny. Orygenes (Comm. in

2 R. Bartnicki, „Tekst Za 9,9-10 w perykopach Mt 21,1-11 i J 12,12-19”, STV 14/2 (1976) 47-65. Główne tezy odnośnie do użycia Za 9,9 w Mt 21,1-11 znajdują się także w R. Bartnicki, „Das Zitat von Zach IX, 9-10 und die Tiere im Bericht von Matthäus über dem Einzug Jesu in Jerusalem (Mt XXI, 1-11)”, NT 18 (1976) 161-166. 
Jo. 10,164) uważa, iż dystans, jaki Jezus miał pokonać (15 stadiów, tj. ok. 3 km), jest zbyt krótki, aby angażować dwa osły. Przez ten fakt tekst Mateuszowy mówiący o siedzeniu Jezusa na dwóch osłach zaprasza do lektury alegorycznej. Hieronim (Comm. in Matt. 3,21) również uważa, iż nie jest możliwym użycie dwojga zwierząt w tak krótkiej podróży, jaką była trasa z Betfage do Jerozolimy. $\mathrm{Z}$ tego powodu Jezus siedział tylko na jednym zwierzęciu - albo na oślicy, albo na młodym źrebięciu. Zdaniem księcia egzegetów narracja Mateusza, mówiąc o rzeczy niemożliwej lub wręcz okropnej (turpitudo), jaką jest jazda Jezusa na dwóch osłach ${ }^{3}$, kieruje nas ku głębszemu sensowi: Ergo cum historia vel impossibilitatem habeat vel turpitudinem, ad altiora transmittimur (PL 26,147; SC 259,104-105). Poniżej przedstawmy zatem kilka przykładów alegorycznej interpretacji Mateuszowej pary osłów.

Już w II w. Justyn (Dialogus cum Tryphone 53,1) identyfikuje oślicę z Żydami, natomiast młodego osiołka - z poganami. Ci pierwsi, symbolizowani przez starą oślicę, mają prawo nadane im przez proroków. Poganie natomiast, jak wyjaśnia Justyn, nie nosili jarzma nauczania do momentu przyjścia Chrystusa i posłania Jego uczniów z misją czynienia uczniów pośród pogan, stąd symbolizowani są przez młodego osiołka, którego nikt jeszcze nie dosiada1 ${ }^{4}$. Orygenes (Comm. in Matt. 16,17) w dwóch uczniach posłanych po osły widzi figurę Piotra i Pawła, jednego posłanego do Żydów, drugiego - do pogan. Konsekwentnie oślica symbolizuje obrzezanych będących pod jarzmem Prawa, podczas gdy młody osiołek - pogan (PG 13,1431-1434). Orygenes stwierdza także wyraźnie, wbrew temu, co sugerują powołujący się na niego współcześni komentatorzy, że Jezus siedział na dwojgu zwierzętach $(16,18)^{5}$. Orygenes w swoim napisanym wcześniej komentarzu do Ewangelii Jana (Comm. in Jo. 10,180) twierdzi, iż oślica oznacza obrzezanych, którzy uwierzyli i zostali uwolnieni od wielu więzów za sprawą innych ludzi pouczonych przez Słowo (idzie najwyraźniej o chrześcijan). Osiołek zaś oznacza wierzących pochodzących z pogaństwa, którzy byli wolni i bez nałożonego jarzma do momentu przyjęcia słowa Jezusa. Przyjęte

3 Rozumienie tekstu Mt 21,7, jako mówiącego o jeździe na dwojgu zwierzętach, potwierdza Hieronim w swej Homilii 7 do Mk 11,1-10. Zob. SC 494,178-181.

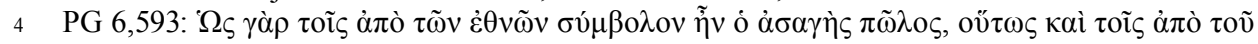

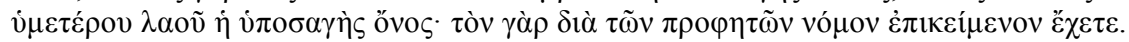

5 Niektórzy komentatorzy stwierdzają, że od opinii Orygenesa zawartej w Comm. in Matt. 16,18 interpretacja Kościoła zawsze wskazywała na szaty, jako miejsce, na którym siedział Jezus: W. Grundmann, Das Evangelium nach Matthäus (ThHNT; Berlin: Evangelische Verlagsanstalt ${ }^{2} 1971$ ) 449; U. Luz, Matthew 21-28. A Commentary (Hermeneia - A Critical and Historical Commentary on the Bible; Minneapolis, MN: Fortress 2005) 8; A. Paciorek, Ewangelia wedlug świętego Mateusza. Rozdziały 14-28 (NKB.NT I/2; Częstochowa: Edycja Świętego Pawła 2005) 313-314. Informacja ta nie jest jednak ścisła. Orygenes bowiem rzeczywiście mówi, że Jezus usiadł na szatach, jednak dwukrotnie stwierdza również w tym samym paragrafie, że Jezus jechał na dwóch osłach. 
nauczanie Jezusa stało się dla nich lekkim jarzmem. Pierwsi, którzy uwierzyli w Jezusa, pochodzili spośród obrzezanych, stąd określający ich symbol starszej oślicy matki. Dopiero na kolejnym etapie dziejów Kościoła do wiary w Jezusa dochodzą poganie, których z tej racji symbolizuje młode oślątko $(10,186)$. Na innym miejscu $(10,164)$ Orygenes stwierdza, iż Jerozolima, do której wjeżdża Jezus, Słowo Boga, jest duszą wierzącego. Stara oślica symbolizuje proste słowa Starego Testamentu, młody osiołek zaś - Nowy Testament (10,174-175; także 10,188). Stare i nowe słowa prawdy zawarte w obu testamentach mają moc oczyszczania duszy. Osły, na których siedzi Jezus, nie dotykają ziemi (stąpając po ubraniach), gdyż siedzący na nich Jezus nie jest ziemskiego pochodzenia, zstąpił z nieba $(10,176)$. W tym samym komentarzu do Ewangelii Jana Orygenes podaje również jeszcze inną alegoryczną interpretację dwóch osłów bazującą na ich identyfikacji z dwoma testamentami (10,178-179). Otóż oślica może symbolizować dźwięki, które przynoszą słowo do duszy. Oślica jest zwierzęciem jucznym, a tekst Starego Testamentu jest wielkim ciężarem i objawia wielki ładunek. Osiołek natomiast nie jest zwierzęciem dźwigającym ciężary. Jak wyjaśnia Orygenes: „Chociaż bowiem wszelkie brzemię Pisma jest ciężkie dla tych, którzy nie potrafią sprostać wzniosłości i lekkości Ducha, to przecież Nowe Pismo ma ciężar mniejszy niż Stare" $(10,179)^{6}$.

W najstarszym łacińskim komentarzu do Ewangelii, autorstwa Fortunatiana z Akwilei (Comm. in Matt. 2,44; CCSL 9,369), oślica oznacza synagogę, która zostaje odwiązana, czyli oswobodzona z Prawa. Młode oślę oznacza chrześcijan, przyszłych wierzących (futurum Christianum), a dokładnie nowy lud składający się z wierzących pochodzących z synagogi. Żaden prorok ST nie był w stanie ujarzmić tych ludzi, zrobił to dopiero Chrystus, co symbolizuje gest siedzenia na źrebięciu. Szaty symbolizują przykazania nauczane przez apostołów. Gest siedzenia na szatach oznacza, że ludzie pouczeni przez apostołów niosą teraz Chrystusa ${ }^{7}$. Według Hieronima (Comm. in Matt. 3,21; PL 26,147; SC 259,104-105) oślica oznacza synagogę, będącą pod jarzmem Prawa. Rozbrykany osiołek reprezentuje natomiast pogan. Posłanie dwóch uczniów ma także sens symboliczny,

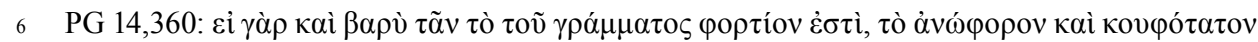

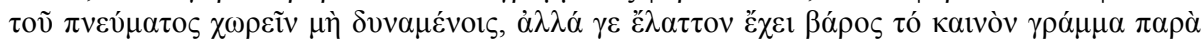
$\tau$ ò $\pi \rho \varepsilon \sigma \beta v ́ \tau \varepsilon \rho o v$. Tł. polskie: Orygenes, Komentarz do Ewangelii wedtug św. Jana (tłum. S. Kalinkowski) (ŹMT 27; Kraków: WAM 2005) 254. Zdaniem Orygenesa (Comm. in Jo. $10,174)$ również dwaj uczniowie przyprowadzający zwierzęta mają sens symboliczny odnoszony do czterech sensów Pisma Świętego, a mianowicie pierwszy z nich oznacza rzeczy napisane w sensie anagogicznym i interpretuje je w sensie alegorycznym. Drugi natomiast demonstruje dobre i prawdziwe rzeczy będące w ukryciu. Być może Orygenes widział tego ucznia jako interpretatora Pisma na sposób moralny.

7 Fortunatianus Aquileiensis, Commentary on the Gospels. English Translation and Introduction (CSEL; Berlin - Boston, MA: De Gruyter 2017) 78. 
jeden jest posłany do obrzezanych, drugi - do pogan ${ }^{8}$. Dydym Aleksandryjski (Comm. in Zac. 3,142; SC 84,690-691), który napisał swój komentarz do Zachariasza za namową Hieronima, widzi w dwojgu zwierzętach dosiadanych przez Chrystusa chrześcijan o dwóch różnych proweniencjach: oślica reprezentuje wierzących pochodzących z obrzezania, osiołek zaś symbolizuje chrześcijan pochodzących ze wszystkich religii pogańskich, tj. idolatrii i kultu demonów

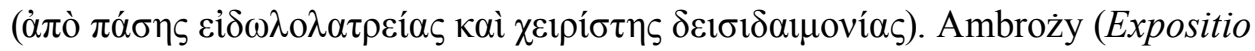
Evangelii secundum Lucam 9,4), nawiązując do płci zwierząt, uważał, że oślica symbolizuje błędy Ewy, natomiast osiołek oznacza ludy pogańskie ${ }^{9}$. Hilary z Poitiers (Comm. in Matt. 21,1; SC 258,120-123) wiąże wzmiankę o dwóch osłach z posłaniem dwóch uczniów symbolizujących dwóch głosicieli Ewangelii posłanych do dwóch ludów: Samarytan (którzy uwierzyli w Jezusa dzięki posłudze Filipa) i pogan (jak Korneliusz, który uwierzył dzięki Piotrowi). Glossa ordinaria (PL 114,152) przejęła tę interpretację, utożsamiając wprost oślicę z Samarytanami oraz źrebię z Korneliuszem i poganami. Jan Chryzostom w swej 66. homilii do Ewangelii Mateusza (PG 58,628) twierdzi, iż osiołek, na którym siedział Jezus, symbolizuje Kościół złożony z pogan, nowy lud Boży, który był nieczysty, jednak stał się czysty poprzez to, że Jezus na nim usiadł. Tak jak apostołowie przyprowadzili osły do Jezusa, również Kościół został przyprowadzony do Jezusa. Jednocześnie oślica symbolizuje samych apostołów, a przez to w domyśle Izrael wierzący w Jezusa. W anonimowym zbiorze homilii do Ewangelii Mateusza, przypisywanym Janowi Chryzostomowi (Homilia 37; PG 56,836), znajdziemy stwierdzenie, iż Jezus, siedząc na dwóch osłach jednocześnie, złączył w jedno pogan i Żydów. Współczesny Janowi Chryzostomowi Apolinary z Laodycei utożsamia oślicę z synagogą, przywiązaną do pierwszego przymierza (zob. Mt 21,2). Na rozkaz Jezusa oślica, symbolizująca synagogę, jest odwiązana od tego przymierza i przyprowadzona do Jezusa, nowego przymierza ${ }^{10}$. Wzorem poprzedników Cezary z Arles (Serm. 113,2) utożsamia oślicę z chrześcijanami pochodzenia żydowskiego i osiołka z chrześcijanami pochodzenia pogańskiego ${ }^{11}$. W ten sam sposób Beda (In Matt. 3,21) widzi w oślicy synagogę, w osiołku zaś

8 W Homilii 7 (SC 494,178-181) Hieronim wskazuje na dwie możliwości. W pierwszej Jezus usiadł na młodym osiołku symbolizującym pogan. W drugiej Jezus usiadł na oślicy symbolizującej tych, którzy pochodzili z synagogi i wierzyli w Jezusa. Hieronim w swej homilii opowiada się za drugim rozwiązaniem: Jezus usiadł na oślicy przyzwyczajonej do jarzma, której grzbiet i barki były wytarte od Prawa.

9 PL 15,1794: ,quia in duobus hominibus uterque fuerat sexus expulsus, in duobus animalibus sexus uterque revocetur; ergo illic in asina matre quasi Evam figuravit erroris, his autem in pullo generalitatem populi gentilis expressit, et ideo in pullo sedetur asinae".

10 J. Reuss, Matthäus-Kommentare aus der griechischen Kirche (TUGaL 61/V.6; Berlin: Akademie Verlag 1957) 35.

11 Caesarius of Arles, Saint Caesarius of Arles. Sermons. II. Sermons 81-186 (The Fathers of the Church 47; Washington, DC: The Catholic University of America Press 1964) 160. 
- narody pogańskie: Asina Synagogam, quae jugum legis traxerat, pullus asinae lascivum ac liberum nationum populum demonstrat (PL 92,90).

Wczesnośredniowieczna Glossa ordinaria interpretuje na sposób duchowy czynność siedzenia Jezusa na osłach jako przebywanie Jezusa w sercach ludów symbolizowanych przez zwierzęta ${ }^{12}$. Teofilakt z Ochrydy (Enarratio in Evangelium Matthaei 21,7; PG 123,269) uważał, że dosiadana wpierw oślica symbolizowała żydowską synagogę, natomiast dosiadany później osiołek - narody pogańskie. Kolejność ta oczywiście odzwierciedla historię zbawienia, w której Jezus działał wpierw wśród Żydów, zaś później Kościół - wśród pogan. Inny autor średniowieczny, Bruno z Segni, uważał, iż w rzeczywistości Jezus siedział tylko na osiołku, jednak w sensie duchowym, w celu wypełnienia proroctwa $\mathrm{Za}$ 9,9, siedział na dwojgu zwierzętach: corporaliter enim super pullum, spiritualiter autem super utrumque Dominus sedit (PL 165,243). Zwierzęta symbolizowały oczywiście synagogę i pogan oraz Stary i Nowy Testament ${ }^{13}$. Interpretacja Tomasza z Akwinu podąża w kierunku wyznaczonym przez egzegezę starożytną i wczesnośredniowieczną. Oślica symbolizująca nawróconych Żydów oraz osiołek symbolizujący nawróconych pogan są przyprowadzone do Jezusa, czyli do wiary w Jezusa. Fakt siedzenia przez Jezusa na obu zwierzętach oznacza, iż Jezus był w sercach zarówno Żydów, jak i pogan ${ }^{14}$.

Interpretacja alegoryczna czy też symboliczna, zapoczątkowana w starożytności i kontynuowana $\mathrm{w}$ średniowieczu, była również powielana w czasach nowożytnych, czego przykładem jest komentarz Corneliusa à Lapide’a, który prócz sensu dosłownego (Jezus dosiadał oba zwierzęta naprzemiennie) widzi w tekście także sens duchowy, zgodnie z którym Jezus dosiadał celowo dwojga zwierząt, chcąc pokazać swe królewskie władanie nad dwoma rodzajami ludzi, a mianowicie Żydami, symbolizowanymi przez oślicę, oraz poganami, których oznaczał osiołek ${ }^{15}$. Marie-Joseph Lagrange razem z innymi współczesnymi komentatorami odrzuca interpretację alegoryczną, twierdząc, iż Mateusz referował fakty ${ }^{16}$.

12 PL 114,152: Non ad litteram super utrumque sedit, sed in praecordiis utriusque populi.

13 Brunonis Signiensis, Comment. in Matth. 85 (PL 165,242-243).

14 Thomas Aquinas, Doctoris Angelici divi Thomae Aquinatis sacri ordinis F.F. Praedicatorum opera omnia [...]. XIX. Commentarium super Matthaeum (Parisiis: apud Ludovicum Vivès, 1876) 531: „Secundum litteram dicitur quod super utrumque, quia super corda Judaeorum et Gentilium".

15 C. à Lapide, Commentaria in Scripturam Sacram [...] editio nova [...]. XV. In SS. Matthaeum et Marcum (Parisiis: Vivès 1867) 459: „Praecipue vero mysterii causa his doubus jumentis voluit uti, ut significaret non solis iis quibus promissus fuerat, scilicet Judaeis, sed toti se mundo, id est duobus populis, quibus constat mundus, regnaturum, Judaeis Mosaicae legis jugo assuetis, quos asina; et Gentibus, sine Dei lege viventibus hactenus, quos pullus figuraret".

16 M.-J. Lagrange, Évangile selon Saint Matthieu (ÉtB; Paris: Gabalda et C $\left.{ }^{\text {ie }} 1923 .{ }^{3} 1927\right) 399$. Zob. Bartnicki, „Tekst Za 9,9-10”, 52; W.D. Davies - D.C. Allison, A Critical and Exegetical 


\section{Interpretacje odwołujące się do pracy redakcyjnej}

Jeśli pozostałe trzy Ewangelie kanoniczne mówią o wjeździe Jezusa na jednym osiołku, można domniemywać, iż Mateusz dokonał świadomej zmiany, wprowadzając - wbrew faktom i tradycji poświadczonej w pozostałych Ewangeliach - dwa osły. Zdaniem Alfreda Loisy'ego redakcyjny zabieg dubletu w przypadku dwóch osłów miałby swoje paralele w podobnych Mateuszowych dubletach, a mianowicie w przypadku dwóch opętanych w krainie Gadareńczyków $(8,28)$ czy dwóch niewidomych pod Jerychem $(20,30)$. W obu paralelnych tekstach Marek $(5,2 ; 10,42)$ i Łukasz $(8,27 ; 18,35)$ wzmiankują jedną osobę. Alfred Loisy uważa, że dwa Mateuszowe osły zachowują się jak jedno zwierzę (Jezus jedzie na nich, co jest rzeczą niemożliwą), gdyż ich podwójność jest jedynie czystym zabiegiem redakcyjnym, bez zakorzenienia w rzeczywistości ${ }^{17}$. Francuski egzegeta nie wyjaśnia jednak motywu tego redakcyjnego dubletu. Marie-Joseph Lagrange odrzuca powyższe wyjaśnienie, stwierdzając, iż tak jak możliwym jest opisanie w identyczny sposób dwóch opętanych czy niewidomych (można skierować do nich te same słowa, a oni także mogą się wypowiedzieć w ten sam sposób), tak nie jest jednak możliwym dosiadanie dwojga zwierząt jednocześnie ${ }^{18}$.

John Nolland wyjaśnia Mateuszowe dublety jako zabieg wskazujący na powtarzalność wydarzeń (np. w odniesieniu do 8,28, egzorcyzmów w posłudze Jezusa musiało być wiele) oraz nawiązujący do żydowskiej praktyki sądowej uznającej za wiarygodne świadectwo dawane przez dwie osoby (zob. Lb 35,30; Pwt 17,6; 19,15). Oba powyższe motywy, jak słusznie przyznaje sam autor, nie mają jednak zastosowania w przypadku dwóch osłów ${ }^{19}$. Craig S. Keener uważa, iż w świetle innych przykładów dublowania postaci w narracji Mateusza $(8,28 ; 9,27 ; 20,30)$ wystąpienie dwóch osłów może być redakcyjnym sposobem na podkreślenie ważności wydarzenia ${ }^{20}$. W podobnym nurcie Pinchas Lapide wskazuje na ducha języka hebrajskiego, w którym poprzez dublet wzmacnia się

Commentary on the Gospel according to Saint Matthew. III. Commentary on Matthew XIXXXVIII (ICC; Edinburgh: T\&T Clark 1997) 121, przyp. 66: „Obviously no allegorical meaning is to be assigned to the two animals".

17 A. Loisy, Les Évangiles synoptiques (Ceffonds près Montier-en-Der [Haute-Marne]: chez l'auteur 1908) II, 263: „Les deux ânes se conduisent comme s'ils n'étaient qu'un, du même que plus haut les deux possédés et les deux aveugles, et pour le même motif: parce que le doublement est le fait du rédacteur".

18 Lagrange, Matthieu, 399.

19 J. Nolland, The Gospel of Matthew. A Commentary on the Greek Text (NIGTC; Grand Rapids, MI - Cambridge, U.K.: Eerdmans 2005) 837. Por. również R.T. France, The Gospel of Matthew (NICNT; Grand Rapids, MI - Cambridge, U.K.: Eerdmans 2007) 779.

20 C.S. Keener, The Gospel of Matthew. A Socio-Rhetorical Commentary (Grand Rapids, MI Cambridge, U.K.: Eerdmans 2009) 492. 
wypowiedź. Pinchas Lapide podaje jako przykład dwa osły w Rdz 49,11 (tekst mesjański) oraz podwojenie imienia Abrahama w Rdz 22,11 i Szawła w Dz 9,4 $4^{21}$.

\section{Interpretacje naturalistyczne}

Terminem „naturalistyczne” określamy interpretacje komentatorów wychodzących z założenia, iż Mateusz dokładnie odwzorował rzeczywistość historyczną: w czasie triumfalnego wjazdu do Jerozolimy Jezus używał dwóch osłów. W tym duchu M.-J. Lagrange stwierdza, iż Mateuszowe wyrażenie ,usiadł na nich” (21,7) oznacza „posłużył się obydwoma w swoim wjeździe" ${ }^{22}$. Z reguły komentatorzy idą nieco dalej niż powyższe ogólne stwierdzenie założyciela École Biblique i próbują szczegółowo określić, w jaki sposób Jezus używał tych zwierząt.

Jedno z najpopularniejszych wyjaśnień odwołuje się do faktu podania przez Mateusza dwóch różnych płci zwierząt. Otóż tekst mówi o żeńskiej oślicy (w domyśle samicy matce) oraz źrebięciu rodzaju męskiego ${ }^{23}$. Znajdujące się w drugim członie cytatu z Za 9,9 dopowiedzenie określające źrebię poprzez

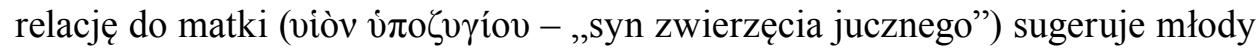
wiek osła. Zwierzęta są przyprowadzone do Jezusa razem. Można zatem wyobrazić sobie sytuację, w której źrebię jest tak młode i niesamodzielne, iż wciąż przebywa ze swoją matką, być może nawet jeszcze go karmiącą. Źrebię mogłoby wręcz spontanicznie przyłączyć się do oślicy zabieranej przez uczniów, gdyż w istocie matka i źrebię tworzą jedność ${ }^{24}$. Oddzielenie matki od źrebięcia mogło jedynie wywołać opór dwojga zwierząt i konsekwentnie stworzyć niepotrzebne trudności w wykonaniu powierzonej uczniom misji. Fakt przywiązania jedynie oślicy (Mt 21,2) również sugeruje młody wiek źrebięcia, które jest wciąż tak ściśle związane z matką, iż nie oddala się samodzielnie od oślicy i nie musi być przywiązane. Jezus mógłby zatem jechać na dorosłej oślicy, a młode źrebię mogło tylko towarzyszyć matce (czy to idąc wolno obok niej, czy też będąc prowadzonym za uzdę).

Możliwy jest także odwrotny scenariusz, odpowiadający paralelnym tekstom pozostałych Ewangelii synoptycznych mówiących o jednym oślęciu rodzaju męskiego (Mk 11,2-5.7; Łk 19,30.33.35) ${ }^{25}$ oraz precyzujących, iż nikt jeszcze nie

21 P. Lapide, Bibbia tradotta Bibbia tradita (Studi Bibilici 36; Bologna: EDB 2000) 176: „il raddoppiamento mira unicamente a un rafforzamento retorico dell'espressione".

22 Lagrange, Matthieu, 399.

23 Mt 21,2.5.7: „oślica” (r.ż. óvov) oraz „źrebię” (r.m. $\pi \tilde{\omega} \lambda$ ov). Mt 21,5: „na źrebaku, synu [zwierzęcia]



24 Miszna (m. Bava Batra 5,3) stwierdza: „Kto sprzedał osła (החמור), sprzedał także źrebię" (הסיח).

25 Janowe ỏvópıov („oślę”) jest rodzaju nijakiego $(12,14)$. Występujący jednak dalej $\pi \tilde{\omega} \lambda$ os („,osioł”) jest rodzaju męskiego $(12,15)$. 
dosiadł owego osła (zob. Mk 11,2; Łk 19,30) ${ }^{26}$. W tym przypadku oślica matka towarzyszyłaby młodemu osiołkowi, na którym jechałby Jezus. Zabranie oślicy wraz z osiołkiem było znakiem roztropności, gdyż obecność samicy matki przy młodym źrebięciu, pośrodku wiwatującego tłumu ludzi, miałaby nań wpływać uspakajająco $^{27}$. Regułą było także, iż samica matka towarzyszyła młodemu źrebięciu wprowadzanemu do pracy jako zwierzę juczne ${ }^{28}$.

Opinie komentatorów są podzielone pomiędzy pierwszą (Jezus jedzie na oślicy) ${ }^{29}$ i drugą możliwość (Jezus jedzie na osiołku), z preferencją dla drugiej ${ }^{30}$. Zdaniem Albrechta Frenza bardziej wiarygodna jest jednak pierwsza opcja, gdyż nieujeżdżony osiołek byłby trudny do okiełznania przez potencjalnego jeźdźca ${ }^{31}$.

Poza powyższymi wyjaśnieniami pojawiły się w historii egzegezy jeszcze cztery inne naturalistyczne propozycje interpretacyjne. Wczesnośredniowieczna Glossa ordinaria twierdzi, iż Jezus dosiadał obojga zwierząt naprzemiennie: Potuit Dominus super utrumque ascendere, descendens de uno et ascendens super alium (PL 114,152). Pogląd ten podziela także Teofilakt z Ochrydy:


i późniejsi komentatorzy ${ }^{32}$. Tworzący w XVII w. Cornelius à Lapide uważał, iż Jezus dosiadał dwojga zwierząt naprzemiennie, gdyż młody osiołek mógł nie być wystarczająco silny, aby zwieźć Jezusa z Góry Oliwnej i następnie wwieźć Go na wzgórze, na którym wznosiły się mury i brama miasta ${ }^{33}$. Interpretacja

26 Wybór osiołka jest także zgodny ze starotestamentowymi prawami poświęcania pierworodnych zwierząt Bogu (zob. Wj 13,2; 34,19) oraz przeznaczania do kultu młodych zwierząt nie będących jeszcze pod jarzmem (zob. Lb 19,2; Pwt 21,3; $1 \mathrm{Sm} 6,7$ ). Por. A.J. Maas, The Gospel according to Saint Matthew with an Explanatory and Critical Commentary (St. Louis, MO: B. Herder 1898) 214.

27 R. Winterbothom („The Ass and the Ass's Colt: St. Matthew xxi. 1-7”, ExpT 28 [1917] 380-381) zasięgnął opinii hodowcy, który stwierdził, iż w sytuacji opisanej przez Mateusza młodemu osiołkowi musiała towarzyszyć samica, inaczej nie można by przekonać źrebięcia do współpracy.

28 Zdaniem C.H. Spurgeona (The Gospel of the Kingdom. A Popular Exposition of the Gospel according to Matthew [New York, NY: Baker \& Taylor 1893] 343) zabranie oślicy wraz z niedojrzałym źrebięciem wskazuje na cechę charakteru Jezusa, jaką była delikatność (tenderness).

29 Np. L.C. Fillion, The Life of Christ. A Historical, Critical, and Apologetic Exposition (St. Louis, MO - London: Herder 1941) III, 239; P. Nepper-Christensen, Das Matthäusevangelium - ein judenchristliches Evangelium? (AThD 1; Aarhus: Universitets-Forlaget 1958) 147; Lapide, Bibbia tradotta, 176.

30 Np. Heronim, Comm. in Matt. 3,21; R.T. France, Matthew. An Introduction and Commentary (Downers Grove, IL: InterVarsity 1985) 302; D.A. Hagner, Matthew 14-28 (WBC 33B; Dallas, TX: Word 1998) 595. J. Maldonatus (A Commentary on the Holy Gospels [London: John Hodges 1888] II, 194) przytacza nieprzekonującą opinię, w świetle której fakt dosiadania przez Jezusa nieujeżdżonego źrebięcia, ujarzmienie tegoż oślęcia, ukazuje Jego nadprzyrodzoną moc.

31 A. Frenz, „Mt XXI 5.7”, NT 13 (1971) 259-260.

32 Interpretację tę spotykamy w dziełach Brunona z Segni (1044-1123), Kajetana (1469-1534), Dionizego Kartuza (1403-1473), Corneliusa a Lapide (zm. 1637), Johannesa de Sylveira (zm. 1687).

33 Lapide, Commentaria, XV, 459: „Verius est Christum tam asinae, quam pullo insedisse non simul, sed successive, ut dixi Zachar. IX,9. Prius asina usus est Jesus, ait Franciscus Lucas, deinde 
mówiąca o naprzemiennym dosiadaniu dwojga zwierząt musiała być znana już w starożytności, gdyż Hieronim (Comm. in Matt. 3,21) krytycznie zauważa, iż dystans, jaki Jezus miałby pokonać, jadąc z Betfage do Jerozolimy, jest zbyt krótki, aby siedzieć na dwojgu zwierzętach. Żyjący w XIX w. David F. Strauss również stwierdził, iż wymiana osła nie była konieczna, co więcej byłaby to niepotrzebna uciążliwość ${ }^{34}$. Należy jednak zauważyć, iż ocena komentatorów na temat długości trasy i uciążliwości towarzyszących podróży, nadto konieczności lub chęci użycia jednego lub dwojga zwierząt, jest zawsze subiektywna i nie może stanowić rozstrzygającego argumentu.

Niemiecki egzegeta Oscar Holtzmann, a za nim Joachim Gnilka, uważał, iż Jezus rzeczywiście jechał na dwóch osłach, z tym że siedział bokiem na oślicy, a mały osiołek służył jedynie jako podnóżek pod Jego stopy ${ }^{35}$. Z punktu widzenia praktycznego czy też technicznego powyższy sposób jazdy wcale nie wydaje się jednak oczywisty i prosty w zastosowaniu ${ }^{36}$.

Mutacją powyższego poglądu jest przekonanie, że Jezus, siedząc bokiem na oślicy, opuszczał obie nogi na jeden jej bok, przy którym szło źrebię, a te same, szerokie szaty zostały zarzucone na oboje zwierząt. W ten sposób w percepcji zewnętrznych obserwatorów Jezus korzystał w czasie swego wjazdu z dwojga zwierząt jednocześnie ${ }^{37}$.

Innym naturalistycznym wyjaśnieniem jest sugestia kolejnego niemieckiego egzegety, Otto Michela, który widzi w Mateuszowej wzmiance o jeździe na dwóch osłach nawiązanie do orientalnego tronu sytuowanego na dwojgu zwierzętach ${ }^{38}$.

pullo: pullus forte par non fuisset ferendo sessori in montis ascensu descensuque, asina minus decuisset ingressum in urbem; itaque foris asina sequente pullo, pullo in civitatem sequente asina vectus est". G.L. Haydock (Haydock's Catholic Bible Commentary [New York: Edward Dunigan and Brother 1859] ad loc.) stwierdza: ,the very general sentiment is, that he first sat upon the ass for a short time, and then mounted the colt". J. MacEvilly (An Exposition of the Gospels of Matthew and Mark [Dublin - New York: M. H. Gill \& Son - Benziger Brothers 1898] 376) komentuje: ,our Lord sat successively on the ass and the colt, using the ass in ascending and descending the hills, and entering the city mounted on the colt".

34 D.F. Strauss, The Life of Jesus Critically Examined, Translated from the Fourth German Edition (London: Swan Sonneschein - New York, NY: Macmillan $\left.{ }^{2} 1892\right) 553$ (,,a superfluous inconvenience”). Zob. także D. Whitby, „A Commentary on the Gospels and Epistles of the New Testament", A Critical and Paraphrase on the Old and New Testament and the Apocrypha (London: Thomas Tegg 1842) IV, 145: ,it seeming not probable to most interpreters, that in so short a journey Christ should ride upon them both".

35 O. Holtzmann, Das Neue Testament nach dem Stuttgarter griechischen Text. I. Die synoptischen Evangelien. Apostelgeschichte (Giessen: Töpelmann 1926) 184; J. Gnilka, Das Matthäusevangelium. II. Kommentar zu Kap. 14,1-28,20 und Einleitungsfragen (HThKNT; Freiburg - Basel - Wien: Herder $\left.{ }^{2} 1992\right) 202$.

36 Luz (Matthew, 8) stwierdza z przekąsem, iż nie chciałby osobiście próbować tego typu jazdy.

37 D.R.A. Hare, Matthew (Interpretation; Louisville, KY: John Knox Press 1993) 239.


(Stuttgart: Kohlhammer 1959) VI, 961: „,der Evangelist offenbar an einen orientalischen Thronsitz über zwei Tieren denkt". 
Interpretacja ta nie jest przekonująca, ponieważ ewangeliści, przedstawiając niezwykle dokładny opis wydarzeń, ze wzmianką o nakładaniu ubrań na zwierzęta, z pewnością wspomnieliby także o tronie. Obecność tronu podkreślałaby również mesjański i królewski charakter wjazdu Jezusa, stąd ewangelista zainteresowany obydwoma powyższymi tematami z pewnością wspomniałby o tym elemencie triumfalnego wjazdu. Nadto trudno wyobrazić sobie umieszczenie tronu na dwojgu zwierzętach o różnej wielkości. Bardziej prawdopodobna jest interpretacja Waltera Grundmanna, który stwierdził, iż szaty założone jednocześnie na oboje zwierząt stworzyły wrażenie szerokiego tronu ${ }^{39}$. Robert $\mathrm{H}$. Smith również podąża za sugestią tronu i widzi w samej liczbie dwojga zwierząt nawiązanie do orientalnej koncepcji tronu bóstw i królów. Tym samym sama liczba dwojga zwierząt wierzchowych, w kontekście starożytnych bliskowschodnich zwyczajów, powinna nieść przesłanie o królewskiej godności jeźdźca ${ }^{40}$.

Podsumowując, warto zauważyć, iż poczynając od artykułu Albrechta Frenza, komentatorzy chętnie wyjaśniają Mateuszową wzmiankę o dwóch osłach jako naturalny sposób pisania o oślicy matce i jej źrebięciu tworzących nierozdzielną jedność, jeden zespó $1^{41}$. Ewangelista zatem, pisząc o czynności siedzenia Jezusa, użył wprawdzie liczby mnogiej (,,usiadł na nich”), w rzeczywistości jednak Jezus usiadł i jechał tylko na jednym zwierzęciu, któremu towarzyszyło, idąc obok, drugie zwierzę ${ }^{42}$. Pozostałe trzy Ewangelie kanoniczne nie wspominają o dwojgu zwierzętach, gdyż w istocie Jezus jechał tylko na jednym z nich, podczas gdy drugie zwierzę, towarzysząc, odgrywało jedynie rolę drugorzędną (czy to jako oślica uspokajająca źrebię, czy też niesamodzielne źrebię towarzyszące matce). Wzmianka o dwojgu zwierzętach byłaby zatem wyrazem Mateuszowej dbałości o dokładne oddanie najmniejszego nawet szczegółu opisywanego wydarzenia ${ }^{43}$.

Roman Bartnicki komentuje powyższe wyjaśnienie następującymi słowami: „Hipoteza ta, jakkolwiek może wyglądać na prawdopodobną, sprawia jednak

39 Grundmann, Matthäus, 449. Podobnie Robert H. Gundry (Matthew. A Commentary on His Literary and Theological Art [Grand Rapids, MI: Eerdmans 1982] 410) i za nim Robert H. Mounce (Matthew [NIBC.NT 1; Peabody, MA: Hendrickson 1991] 195) sugerują, iż szaty zarzucone na oboje zwierząt i Jezus siedzący bokiem na niższym źrebięciu i mający za placami wyższą oślicę, dały wrażenie istnienia szerokiego tronu.

40 R.H. Smith, Matthew (ACNT; Minneapolis, MN: Augsburg Publishing House 1989) 244: „[Matthew] pictures Jesus the way ancient oriental gods and kings are frequently depicted: enthroned above a pair of animal. He comes meek but royal nonetheless".

41 Hagner, Matthew, 595: ,the two animals, which were kept so closely together, are conceptually regarded as a single, inseparable unit [...], despite the plural language".

42 Zdaniem A. Frenza („Mt XXI 5.7”, 259-260) traktowanie obojga zwierząt jako jedności wyjaśnia także Mateuszową wzmiankę o nałożeniu na nie szat. W istocie mogły one zostać nałożone tylko na oślicę.

43 Mówiąc o Mateuszu w kontekście dwóch osłów w Mt 21,1-11, G.M. Styler („The Priority of Mark", The Two-Source Hypothesis. A Critical Appraisal [red. A.J. Bellinzoni] [Macon, GA: Mercer University Press 1985] 71) stwierdza, że „he is somewhat pedantic”. 
wrażenie interpretacji czysto naturalistycznej” ${ }^{44}$. Jeśli przyjmiemy, że Mateusz chce wiernie relacjonować fakty, nie można wykluczyć powyższego naturalistycznego wyjaśnienia. Warto jednak pamiętać, że Mateusz, opowiadając nawet o faktach, wskazuje na ich teologiczne znaczenie, często poprzez powiązanie z mesjańskimi zapowiedziami ST. Obok zatem naturalistycznego wyjaśnienia obecności dwojga zwierząt winniśmy także szukać teologicznego uzasadnienia ich obecności.

\section{Interpretacje odwołujące się do intertekstualności}

W ramach intertekstualności, czy też egzegezy wewnątrzbiblijnej, obecność dwóch osłów w narracji Mateusza można wyjaśnić na cztery sposoby. Pierwszym jest aluzja do Rdz 49,11, drugim - aluzja do Ha 3,2, trzecim - aluzja do cytatu z Za 9,9 w Mt 21,5, czwartym - typologiczne nawiązania do postaci Mojżesza oraz Dawida i Salomona ${ }^{45}$. Nie można wykluczyć nawiązania do więcej niż jednego lub nawet wszystkich powyższych starotestamentalnych tekstów i postaci.

\subsection{Aluzja do Rdz 49,11}

J. Duncan M. Derrett uważa, że ewangeliści, pisząc o ośle w czasie triumfalnego wjazdu Jezusa do świątyni, łączyli go z proroctwem zawartym w Rdz 49,11.14, w którym występują dwa osły: jeden oznaczający Judę $(49,11)$ oraz drugi oznaczający Issachara $(49,14)$. W tekście Rdz 19,11 mamy do czynienia z parallelis-

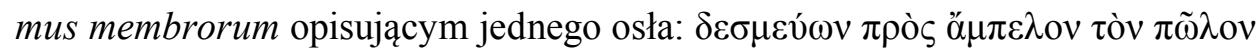

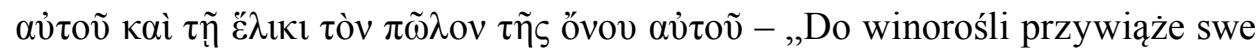
źrebię, źrebię swego osła do młodego pędu" (tłum. R. Popowski). Związek z narracją ewangeliczną bazuje na wspólnym fakcie przywiązania osłów (Rdz 49,11 - $\delta \varepsilon \sigma \mu \varepsilon v ́ \omega ;$ Mt 21,2; Mk 11,2; Łk 19,30 - $\delta \varepsilon ́ \omega)$. Zdaniem J.D.M. Derretta nawiązanie do Rdz 49,11 miałoby wskazać na mesjańską tożsamość Jezusa jako królewskiego potomka Judy ${ }^{46}$. Issachar zdefiniowany jest jako niewolnik $(\operatorname{Rdz} 49,15)$ i to na ośle symbolizującym Issachara, zdaniem J.D.M. Derretta, Jezus miałby wjeżdżać do Jerozolimy ${ }^{47}$. W opinii brytyjskiego egzegety

44 Bartnicki, „Tekst Za 9,9-10”, 53.

45 Na temat metodologii, nazewnictwa i sposobu użycia ST w tekście NT, zob. A. Kubiś, „Drzewo figowe, osioł i woda żywa. Rola Księgi Zachariasza w Ewangelii Janowej”, Resovia Sacra 22 (2015) 211-221.

46 J.D.M. Derrett, „Law in the New Testament: The Palm Sunday Colt”, NT 13 (1971) 255.

47 Derrett, „Law”, 256. 
Mateusz, wspominając o dwóch osłach, chce ukazać wypełnienie się dwóch zapowiedzi ST: Rdz 49 oraz Za 9,9. Tożsamość obu osłów winna być jednak wyjaśniona na podstawie Rdz 49,11.14 ${ }^{48}$. Interpretację tę wspiera także Wilhelmus Weren, sugerując wpływ opisu Issachara w hebrajskim tekście Rdz 49,14-15, jako zwierzęcia jucznego, na Mateuszowy opis oślicy na końcu cytatu w 21,5. Wpływ ten nie jest jednak konieczny, gdyż odwołanie do hebrajskiego tekstu Za 9,9 dostarcza wystarczającej paraleli dla tekstu Mateusza. Nadto, zdaniem W. Werena, Mateuszowe odwołanie do Issachara z Rdz 49,14-15 opisuje Jezusa jako tego, który bierze na siebie ciężary innych (por. Mt 8,17) ${ }^{49}$. Trudno jednak przyjąć, iż Mateusz chce identyfikować Jezusa z oślicą z Rdz 49,14-15. Zamiarem ewangelisty jest raczej identyfikacja Jezusa z mesjańskim jeźdźcem z Za 9,9, cytowanym w Mt 21,5. Urlich Luz odrzuca sugestię odnośnie do bezpośredniego związku Rdz 49 z narracją o wjeździe Jezusa do Jerozolimy na podstawie braku zgodności rodzajów. Otóż w Rdz 49,11 przywiązane zwierzę jest źrebięciem rodzaju męskiego, a w Mt 21,2 jest to oślica ${ }^{50}$. Wielu egzegetów dostrzega jednak możliwość wpływu Rdz 49,10-12 na Za 9,951. Oba teksty już w starożytności interpretowane były w kluczu oczekiwań mesjańskich ${ }^{52}$. Możliwy jest także wpływ Rdz 49,11 na ewangeliczne opisy triumfalnego wjazdu Jezusa, zwłaszcza w wersji Marka ${ }^{53}$ i Jana $^{54}$. Warto odnotować, iż definiowanie

48 Derrett, „Law”, 257: „St. Matthew has not incompetently misunderstood the Zechariah passage. Nor does he fail to notice the semitic idiom. He is to be visualized as hinting that though Zech. ix 9 mentions one animal twice, there must have been two animals in terms of the symbolism, because if one is Issachar, the other is the cold tied to the vine".

49 W. Weren, ,Jesus' Entry into Jerusalem. Mt 21,1-17 in the Light of the Hebrew Bible and the Septuagint", The Scriptures in the Gospels (red. C.M. Tuckett) (BETL 131; Leuven: Leuven University Press - Peeters 1997) 132-133. R.H. Gundry (Commentary on the New Testament. Verse-by-Verse Explanation with a Literal Translation [Peabody, MA: Hendrickson Publishers

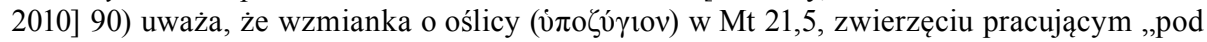

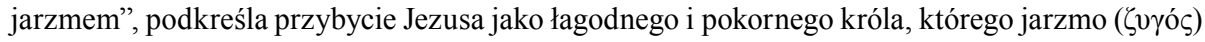
jest wygodne, a ciężar lekki (Mt 11,30).

50 Luz, Matthew, 6.

51 Zdaniem Josepha Blenkisoppa Za 9,9 jest mesjańską reinterpretacją Rdz 49,10-11. J. Blenkinsopp, „The Oracle of Judah and the Messianic Entry”, JBL 80 (1961) 55-64.

52 Co do mesjańskiej interpretacji Rdz 49,8-12 zob. 4QPBless (4Q252) V, 1-7. Oba teksty łączone są z Mesjaszem w Midrasz Rabba Rdz 75,6; 98,9; 99,8. Mesjańska egzegeza Za 9,9 znajduje się także w Talmudzie Babilońskim (b. Ber. 56b, b. Sanh. 98a, b. Sanh. 99a). Oba teksty (Rdz 49,1011 i Za 9,9) łączone są także w najwcześniejszej egzegezie chrześcijańskiej, a mianowicie przez Justyna (Dial. 53; PG 6,591-594) i Klemensa Aleksandryjskiego (Paed. 1,38; PG 7,267-268).

53 H.W. Kuhn, „Das Reittier Jesu in der Einzugsgeschichte des Markusevangeliums”, ZNW 50 (1959) 82-91; D. Krause, „The One who Comes Unbinding the Blessing of Judah: Mark 11.1-10 as a Midrash on Genesis 49.11, Zechariah 9.9, and Psalm 118.25-26", Early Christian Interpretation of the Scriptures of Israel. Investigations and Proposals (red. C.A. Evans J.A. Sanders) (JSNT.S 148; Sheffield: Sheffield Academic Press 1997) 141-153.

54 B.G. Schuchard, Scripture within Scripture. The Interrelationship of Form and Function in the Explicit Old Testament Citations in the Gospel of John (SBLDS 133; Atlanta, GA: Scholars Press 1992) 82-83. 
źrebięcia przez relację do oślicy występuje zarówno w Rdz 49,11, jak i w Mt 21,5. Wobec powyższego nie można wykluczyć istnienia w Mt 21,1-11 echa wyroczni Rdz 49,11, interpretowanej na sposób mesjański ${ }^{55}$. Trudno tu jednak mówić o bezpośredniej aluzji czy cytacie. Zaproponowana identyfikacja dwóch osłów z Judą i Issacharem posiada jedynie walor alegoryczno-symboliczny, który nie wydaje się tutaj najważniejszym zamiarem ewangelisty.

\subsection{Aluzja do Ha 3,2}

W wersji greckiej tekstu proroctwa Habakuka czytamy, iż Bóg (אúpıৎ) zostanie

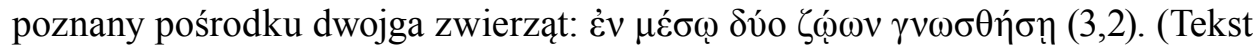
masorecki mówi o ożywieniu dzieł Boga pośrodku lat). Cezary z Arles (Serm. 107,1) łączy tekst Ha 3,2 LXX z triumfalnym wjazdem Jezusa do Jerozolimy, gdzie w sensie duchowym dwoje zwierząt rozumianych jest jako Stary i Nowy Testament. Jezus zatem jest rozpoznany w obu testamentach, czy też objawia się w wewnętrznym sensie obu testamentów. Literatura rabinacka, w tym także Targum, nie interpretuje jednak tekstu Ha 3,2 w sensie mesjańskim, idąc za rozumieniem wyroczni poświadczonym w tekście hebrajskim ${ }^{56}$. Nie wydaje się zatem właściwym przypisywanie temu tekstowi wpływu na ostateczny kształt Mt 21,1-11 $1^{57}$.

55 Zob. Weren, „Jesus' Entry into Jerusalem”, 133: „the scene of Jesus' entry contains implicit citations from Gen 49,8-12.14"; Mitch C. - E. Sri, The Gospel of Matthew (CCSS; Grand Rapids, MI: Baker Academic 2010) 265: „Matthew mentions the two animals to accentuate the parallels with the royal prophecies of Gen 49:10-11 and Zech 9:9 - which each involve a mother ass and the cold".

56 Przegląd interpretacji żydowskich w Y. Stavsky, Trei asar. The Twelve Prophets. A New Translation with a Commentary Anthologized from Talmudic, Midrashic, and Rabbinic Sources. II. Micah, Nahum, Habakkuk, Zephania, Haggai, Zechariah, Malachi (The ArtScroll Tanach Series; Brooklyn, NY: Mesorah 2009) 120.

57 Apokryficzna Ewangelia Pseudo-Mateusza (rozdział 14.) wypełnienie proroctwa Ha 3,2 widzi w umieszczeniu nowo narodzonego Jezusa w stajni, pomiędzy wołem i osłem. Ojcowie Kościoła

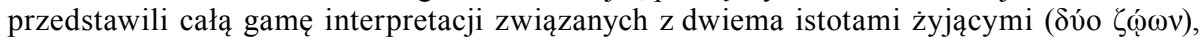
jednak nie wiążą ich z dwoma osłami z triumfalnego wjazdu Jezusa do Jerozolimy. Teodor z Mopsuestii i Teodoret z Cyru widzą w nich Judejczyków i Babilończyków. Orygenes widzi w całym obrazie objawienie Trójcy Świętej: oto Bóg objawia się pomiędzy Synem i Duchem, tak jak w świątyni Bóg objawiał się pomiędzy dwoma cherubami na przebłagalni. Cyryl Aleksandryjski również mówi o dwóch cherubach przebłagalni. Hezychiusz z Jerozolimy widzi w żywych istotach dwóch łotrów, pośród których ukrzyżowany był Jezus. Augustyn podał trzy interpretacje: pomiędzy dwoma przymierzami, pomiędzy dwoma łotrami, pomiędzy Mojżeszem i Eliaszem. Teoretycznie istnieje także możliwość interpretowania greckiego zapisu

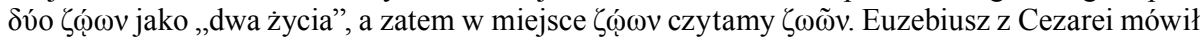
zatem o objawieniu się Jezusa pośród życia ludzkiego i życia boskiego, pomiędzy swą naturą boską i ludzką. Dla Cyryla Aleksandryjskiego i Augustyna dwa życia mogą być figurą dwóch testamentów. Dla Teodoreta z Cyru oraz Cyryla Jerozolimskiego dwa życia oznaczają życie 


\subsection{Aluzja do cytatu z Za 9,9 w Mt 21,5}

Związek między Mateuszową relacją o wydarzeniu wjazdu i cytatem z Za 9,9 jest niezwykle wyraźny. Ewangelista wprowadza bowiem cytat słowami: „Stało się tak, aby spełniło się słowo powiedziane przez proroka” $(21,4)$. Cytat jest zatem wprowadzony formułą wskazującą, iż relacjonowane wydarzenie jest spełnieniem się zapowiedzi zawartej w wyroczni prorockiej. Proroctwo winno więc w jakiś sposób odpowiadać wydarzeniu, a wydarzenie - proroctwu. Obecność dwóch osłów może być zatem interpretowana poprzez pryzmat prorockiej zapowiedzi wjazdu mesjańskiego w Za 9,9. Nie tylko treść formuły wprowadzającej cytat, ale także centralna pozycja cytatu w narracji Mateusza podkreśla jego kluczową funkcję dla zrozumienia logiki narracji. Perykopa ma następujący schemat:

(a) Jezus posyła dwóch uczniów z misją przyprowadzeniu dwóch osłów (w. 1-3)

(b) Zapowiedź proroka o wjeździe Mesjasza na ośle/osłach (w. 4-5)

(a') Dwaj uczniowie przyprowadzają dwa osły i Jezus wsiada na osły (w. 6-7)

Jak zauważa Maarten J.J. Menken, umieszczenie cytatu ze ST (w. 5) przed opisem wykonania rozkazu (w. 6-7) służy pokazaniu zbieżności pomiędzy wykonaniem polecenia Jezusa oraz wypełnieniem proroctwa ${ }^{58}$.

Interesujący nas fragment cytowanego przez Mateusza tekstu prorockiego składa się z dziewięciu wyrazów, podobnie jak tekst masorecki:

\begin{tabular}{|c|c|}
\hline Za 9,9 & Mt 21,5 \\
\hline ורכב & 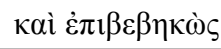 \\
\hline על־חמור & 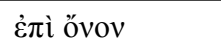 \\
\hline ועל־עיר &  \\
\hline בן־אתנות & 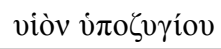 \\
\hline
\end{tabular}

Zarówno w tekście Zachariasza, jak i Mateusza występuje identyczna sekwencja

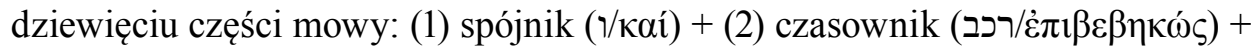

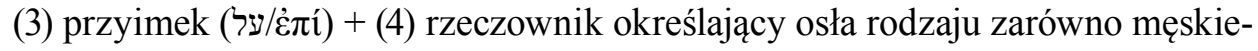

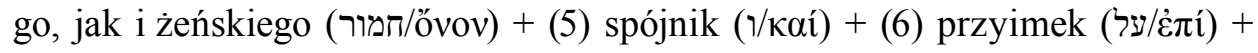

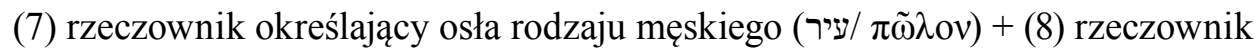
„syn” (בן/vióv) + (9) rzeczownik określający zwierzę (r.ż. 1.mn. אתנות / r.n. 1.p.

obecne i życie przyszłe, a więc życie ziemskie i życie niebiańskie po śmierci. Za M. Harl C. Dogniez - L. Brottier - M. Casevitz - P. Sandevoir (red.), La Bible d'Alexandrie. XXIII. Les douze prophètes. 4-9. Joël, Abdiou, Jonas, Naoum, Ambakoum, Sophonie (Paris: Cerf 1999) 250.

58 M.J.J. Menken, „Context and Textual Form of the Quotation from Zechariah 9,9 in Matthew 21,5”, Matthew's Bible. The Old Testament Text of the Evangelist (BEThL 173; Leuven: Leuven University Press - Peeters 2004) 107. 


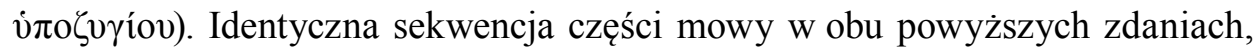
wraz z identycznym zakresem semantycznym kolejnych wyrazów, jest mocnym argumentem za uznaniem tezy o korzystaniu przez Mateusza z tekstu hebrajskiego Za 9,9 $9^{59}$.

Odnośnie do znaczenia tekstu wyroczni, Zachariasz stwierdza, iż sprawiedliwy, zwycięski i pokorny król przybywa do Jerozolimy, jadąc na ośle. Opis osła komentatorzy definiują często jako parallelismus membrorum ${ }^{60}$. Spójnik wāw (nr 5 powyżej) łączy zatem dwa człony paralelizmu. Forma i treść powyższego tekstu wyklucza paralelizm antytetyczny. Zgodnie z zasadami poetyki hebrajskiej w paralelizmie synonimicznym czy też semantycznym drugi człon paralelizmu opisuje paralelną treść w stosunku do treści pierwszego członu, używając jednak do tego synonimicznych terminów. Jeśli powyższy tekst Za 9,9 zakwalifikujemy jako paralelizm synonimiczny, wówczas dwa człony paralelizmu mówią o jednym i tym samym ośle. Robert Alter uważa, iż poza ograniczoną liczbą statycznych paralelizmów semantycznych (gdzie oba człony, używając innych terminów, opisują dokładnie tak samo identyczną rzeczywistość), w większości paralelizmów spotykanych w Biblii hebrajskiej drugi człon zawsze dodaje do członu pierwszego nowe znaczenie, np. doprecyzowanie ${ }^{61}$.

Paralelizm z Za 9,9 można również zdefiniować jako paralelizm eliptyczny, czyli taki, w którym czasownik występuje jedynie w pierwszym członie. Drugi człon pozbawiony czasownika pozwala na dopracowanie i wyostrzenie znaczenia. Zdaniem R. Altera brak czasownika w drugim członie skupia uwagę na dopełnieniu czasownika znajdującym się w drugim członie. Drugi człon w takim przypadku przedstawia bardziej dopracowany opis, bardziej przemawiający do wyobraźni, także przy użyciu większej liczby wyrazów ${ }^{62}$. Odnośnie do liczby

59 Wśród egzegetów istnieją przynajmniej cztery poglądy na temat Mateuszowego Vorlage dla cytatu z Za 9,9. Poza przyjętą przez nas tezą o tłumaczeniu z hebrajskiego (tak również uważają Lohmeyer, Strecker, Moo, Miler) część autorów twierdzi, iż część cytatu pochodzi z LXX, a część - z tekstu hebrajskiego (Allen, Lindars, Gundry, Grundmann, Beare, Davies, Allison, Weren, Nieuviarts). W świetle dwóch kolejnych opinii Mateusz zmodyfikował tekst LXX (New) lub też korzystał z rewizji LXX (Aejmelaeus, Wilcox, Menken). Odniesienia bibliograficzne do dzieł wspomnianych autorów w Menken, „Context”, 112-113.

60 Dla przykładu, R.L. Smith, Micah-Malachi (WBC 32; Waco, TX: Word Book 1984) 255: „The poetic parallelism is very obvious". Szeroki opis struktury paralelizmu w tekście hebrajskim Za 9,9 przedstawia M. Mulzer, „Ein Esel, zwei Esel? Zu Sach 9,9 und Mt 21,2.5.7”, BZ 59 (2015) 80-83.

61 R. Alter, The Art of Biblical Poetry (New York: Basic Books 1985) 18-22, szczególnie 19: „In the abundant instances [...] in which semantic parallelism does occur in a line, the characteristic movement of meaning is one of heightening or intensification (as in the paradigmatic case of numerals), of focusing, specification, concretization, even what could be called dramatization. $[\ldots]$ The rule of thumb [...] is that the general term occurs in the first verset and a more specific instance of the general category in the second verset”. Oczywiście są także (nieliczne) przykłady sytuacji odwrotnej: pierwszy człon jest bardziej szczegółowy niż ogólny człon drugi.

62 Alter, The Art of Biblical Poetry, 24: „Often what happens is that the second term, where the poet has room for introducing a compound form or a compact cluster of nouns or nouns and 
zwierząt, sens interesującego nas paralelizmu synonimicznego, mającego formę paralelizmu eliptycznego, wskazuje, iż król wjeżdża na jednym ośle.

Także gramatyka hebrajska wskazuje na rozumienie Za 9,9 jako mówiącego o jednym ośle, gdyż spójnik wāw może być rozumiany przynajmniej na trzy sposoby: (1) jako element hendiadys, (2) jako łączący dwa elementy w apozycji, (3) czy też jako wāw explicativum ${ }^{63}$. W każdym z powyższych trzech przypadków tekst wyroczni można przetłumaczyć w taki sposób, iż drugi człon dookreśla znaczenie pierwszego członu.

Pozostaje jednak kwestia semantyczna, a mianowicie znaczenie drugiego członu, który ma doprecyzować znaczenie pierwszego. W literaturze napotykamy dwa sposoby rozumienia i tłumaczenia drugiego członu. W pierwszym ujęciu akcentuje się młodość osła i tłumaczy: ,jedzie na ośle, czyli na źrebięciu oślicy" ${ }^{\circ 4}$. W drugim ujęciu wskazuje się na czystość rasy osła, wykluczając jego identyfikację z mułem. Otrzymujemy wówczas tłumaczenie: ,jedzie na ośle, na czystej krwi ośle" ${ }^{65}$.

Pierwsze tłumaczenie napotyka trudność logiczną. Otóż kontekst Za 9,9 nakazuje interpretować jazdę na ośle jako znak pokoju, w kontraście do jazdy na koniu jako znaku wojny (Za 9,10). Osioł z pewnością nie jest rumakiem wojennym, jest nim natomiast koń i rydwany. Młodość czy też brak ujeżdżenia osła nie podkreśla jednak idei pokoju. Logika narracji nakazuje zatem faworyzować rozwiązanie drugie, podkreślające czystość rasy ${ }^{66}$.

qualifiers, is an elaboration of the first term that makes its meaning more vividly present to imagination".

63 W. Gesenius, Gesenius's Hebrew and Chaldee Lexicon to the Old Testament Scriptures (Grand Rapids, MI: Eerdmans 1950) 234; GKC $\S 154$, przypis $1 b$.

64 C.F. Keil - F. Delitzsch, Commentary on the Old Testament. X. The Minor Prophets (Peabody, MA: Hendrickson 2006) 576: ,riding upon an ass, and indeed upon the foal of an ass”. C.F. Keil, autor komentarza do Księgi Zachariasza, dodaje (ibidem, 576), iż spójnik wāw wprowadzający drugi człon ma walor eksplikatywny (epexegetical), opisując osła jako młode zwierzę, którego nikt jeszcze nie dosiadał i które wciąż towarzyszy oślicy matce.

65 Zob. A. Wolters, Zechariah (HCOT; Leuven - Paris - Walpole, MA: Peeters 2014) 280: „on a donkey, on a purebred male donkey".

66 Istnieją oczywiście próby ukazania głównego przesłania tekstu nie w (1) idei pokoju, ale w (2) pokorze przyszłego króla (np. C.F. Keil) lub też w (3) sakralnym, liturgicznym charakterze misji króla, który używa zwierzęcia, na które nie było włożone jarzmo, a zatem zwierzęcia zdatnego do ofiarowania go w kulcie (Lb 19,2; Pwt 21,3) lub wykorzystania go w kontekście sakralnym (1 Sm 6,7) (np. K. Koeher). Zob. Keil - Delitzsch, Commentary, 576-578. K.C. Way zasugerował także, iż Za 9,9 koncentruje się na (4) czystości rasy osła, gdyż muł jako hybryda gatunków byłby nieodpowiednim wierzchowcem w tekście eschatologicznym i nawiązującym do terminologii przymierza (zob. Za 9,11: „krew twojego przymierza”). Teksty z Mari informują, iż krzyżówki zwierząt były wykluczone z ofiar towarzyszących zawieraniu przymierza. Zob. K.C. Way, „Donkey Domain: Zechariah 9:9 and Lexical Semantics”, JBL 129 (2010) 114. Istnieje także interpretacja, w świetle której osioł ma być (5) wierzchowcem królewskim par excellence na starożytnym Bliskim Wschodzie. Zasiadanie na ośle miałoby zatem podkreślać królewską godność jeźdźca. Tak E. Lipiński, „Recherches sur le livre de Zacharie”, VT 20 
$\mathrm{Z}$ pomocą $\mathrm{w}$ wyborze właściwego tłumaczenia przychodzi także analiza semantyczna. Otóż występujący w pierwszym członie termin חמור jest standardowym biblijnym określeniem udomowionego osła (Equus asinus), jednak bez specyfikacji płci. Możemy tutaj mieć do czynienia zarówno z osłem (zob. Ez 23,20), jak i oślicą (zob. 2 Sm 19,27) S7 $^{67}$ Drugi człon używa terminu który określa ogiera, a zatem zwierzę rodzaju męskiego (zob. Rdz 32,16). Może to być jednak zarówno osioł, jak i muł. Z całą pewnością jednak termin ten nie określa „młodego osła” czy „źrebięcia”, jak sugeruje wiele tłumaczeń Za 9,9, będących pod wpływem tłumaczenia $\pi \tilde{\omega} \lambda$ o (,,młode zwierzę”) w LXX Za 9,968. Trzecie i ostatnie określenie zawiera zatem kolejne uszczegółowienie wyrażone przez syntagmę בתון zawsze określa oślicę ${ }^{69}$, stąd możemy przetłumaczyć Zachariaszową syntagmę jako „syn oślicy”. Trzykrotnie w tekstach z Mari (A.1056:9-10; A.2226:17; ARM 2.37:11) występuje analogiczny zwrot (mār atānim) i służy tam do dookreślenia osłów (עיר = hayarum) w kontraście do mułów ${ }^{70}$. Paralelny zwrot (בני אתנו - oślica jest jednak w 1.p.) spotykamy w Rdz 49,11, gdzie również definiuje on ogiera (עיר) jako osła ${ }^{71}$. Wyrażenie ,syn oślicy” w Za 9,9 dookreśla zatem ogiera jako osła. Oba człony paralelizmu w Za 9,9 opisujące osła posuwają się zatem od ogólności do szczegółu, dodając nowe informacje, używając w tym celu trzech określeń: (1) zwierzę gatunku osła, (2) ogier, a zatem zwierzę rodzaju męskiego, (3) urodzone z oślicy, a zatem czystej krwi osiol ${ }^{72}$. Podsumowując sens tekstu opisującego osła w Za 9,9, król wjeżdża do Jerozolimy na jednym ośle, płci męskiej, który jest czystej krwi osłem.

Wracając do użycia Za 9,9 w narracji Mateusza, komentatorzy wyróżniają cztery możliwe i nawzajem wykluczające się sposoby korzystania przez

(1970) 51-52. Warto podkreślić, iż przykłady pozabiblijne podawane przez E. Lipińskiego pochodzą z Ur i Mari z drugiego milenium przed Chr. W czasach powstawania proroctwa Za 9,9 królewskim wierzchowcem był jednak bez wątpienia koń. Można także spojrzeć na wybór osła w Za 9,9 jako na (6) nawiązanie do Rdz 49,11. W ten sposób osioł byłby wskazówką, iż jadący na nim król jest mesjańskim potomkiem Judy. Różne interpretacje, ze wskazaniem na pierwszą jako najbardziej odpowiadającą kontekstowi, omawiają C.L. Meyers - E.M. Meyers, Zechariah 9-14 (AncB 25C; New York, NY: Doubleday 1993) 129-131.

67 Szczegółowa analiza semantyczna tego terminu w Way, „Donkey Domain”, 109-110; K.C. Way, Donkeys in the Biblical World. Ceremony and Symbol (HACL 2; Winona Lake, IN: Eisenbrauns 2011) 164-166.

68 Biblijną semantykę terminu hebrajskiego, wraz z różnymi tłumaczeniami Za 9,9, szeroko omawia Way, „Donkey Domain”, 110-111; Way, Donkeys, 166-168.

69 Szczegółowa analiza semantyczna w Way, „Donkey Domain”, 107-108.

70 Powiązanie Za 9,9 z tekstami z Mari jako pierwszy odnotował W.F. Albright (ANET 482). Szczegółowa analiza powyższych tekstów z Mari w Way, Donkeys, 75-82.

71 E.A. Speiser, Genesis. Introduction, Translation, and Notes (AncB 1; New York, NY: Doubleday 1964) 366.

72 Way, „Donkey Domain”, 108: „In this verse the terminology moves from the general phrase «on a donkey» (על־חמור) to the more specific phrase «on a purebred jackass» (ועל־עיר בן־אתנות). The copulative $w \bar{a} w$ is therefore best interpreted as serving an explanatory function («namely»)". 
ewangelistę z proroctwa Zachariasza. W pierwszym Mateusz miałby niewłaściwie wykorzystać paralelizm synonimiczny, widząc w dwu członach paralelizmu dwoje różnych zwierząt: oślicę i osła. W tym wyjaśnieniu Mateusz ignorowałby zasadę poprawnego rozumienia paralelizmu synonimicznego, która odczytuje w obu członach paralelizmu jedno zwierzę płci męskiej. Według drugiego wyjaśnienia Mateusz zachowałby zasadę paralelizmu synonimicznego, odczytującą w Za 9,9 jednego osła płci męskiej, ale uwzględniłby również obecność oślicy w drugim członie paralelizmu. W świetle trzeciego wyjaśnienia Mateusz respektował regułę paralelizmu synonimicznego i widział w nim jedynie jedno zwierzę. W świetle czwartego wyjaśnienia Mateusz interpretowałby paralelizm jako syntaktyczny, czyli mówiący o dwóch osłach. Poniżej omówimy dokładniej cztery powyższe stanowiska.

\subsubsection{Mateusz ignoruje zasadę paralelizmu w Za 9,9 i widzi tam dwa osły}

Zasada paralelizmu synonimicznego nakazuje widzenie w tekście Za 9,9 jednego osła płci męskiej. Zdaniem niektórych komentatorów Mateusz miałby złamać tę zasadę i przytoczyć dosłownie cytat z Za 9,9 jako prorocką zapowiedź obecności dwóch osłów ${ }^{73}$. Zdaniem tychże komentatorów Mateuszowa dosłowność w przytoczeniu cytatu Za 9,9, łamiąca zasadę paralelizmu, może mieć pięć motywów. Otóż (1) Mateusz oparł się na greckim tekście wyroczni, który wzmiankuje dwoje zwierząt. (2) Mateusz bazował na recenzji tekstu LXX, która mogła sugerować istnienie dwojga zwierząt. (3) W opinii znacznej grupy egzegetów Mateusz nie znał zasady paralelizmu obecnego w Za 9,9. (4) Pojawił się także pogląd, iż Mateusz przytoczył i zinterpretował dosłownie tekst Za 9,9 ze względu na przekonanie o niezmienności tekstu biblijnego. (5) W świetle innego jeszcze poglądu Mateusz świadomie interpretował paralelizm na sposób dosłowny, gdyż rozumiał go zgodnie z ówczesnymi zasadami hermeneutycznymi jako tekst prawny. Poniżej przybliżymy dokładniej pięć powyższych stanowisk.

LXX jako Vorlage. Jacques Dupont sugeruje, iż Mateusz posługiwał się greckim tekstem proroctwa Zachariasza zaczerpniętym z LXX: غ̇ंì vं $\pi \tilde{\omega} \lambda$ ov vย́ov - „na zwierzęciu jucznym i oślęciu młodym”. Zdaniem francuskiego

73 Loisy, Les Évangiles synoptiques, 263; D.J. Harrington, The Gospel of Matthew (Sacra Pagina 1; Collegeville, MN: The Liturgical Press 1991) 293 („The doubling of the animals may be due to Matthew's literal reading of the parallelism in Zech 9,9”); Luz, Matthew, 5-6 (,[...] it was natural for an author who is interested in the literal fulfillment of biblical predictions to speak of two animals. [...] Matthew [...] consciously made use of it [parallelismus membrorum] in the service of his own idea of the literal fulfillment of a scriptural prediction"). 
egzegety tekst ten miałby wyraźnie mówić o dwojgu zwierzętach ${ }^{74}$. W istocie

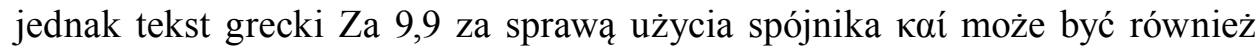
odczytany jako paralelizm synonimiczny i opisywać jedno zwierzę. Taki sam sens otrzymuje się, gdy kaí będzie rozumiane jako kai epexegeticum czy explicativum. Otrzymujemy wówczas tłumaczenie: ,na zwierzęciu jucznym, czyli na młodym ośle" ${ }^{75}$. Pojedyncze użycie przyimka غ̇ंí również sugeruje jedno zwierzę ${ }^{76}$. Niezwykła zgodność między tekstem hebrajskim Za 9,9 i greckim tekstem cytatu w Mt 21,5, w odniesieniu do opisu osłów, każe jednak przypuszczać, iż Mateusz nie cytował w tym miejscu LXX.

Recenzja LXX jako Vorlage. Marten J.J. Menken uważa, iż Mateusz, cytując Za 9,9, oparł się na greckiej rewizji LXX, w której występował rzeczownik ővos, ale bez rodzajnika. Jako że rzeczownik ten może być rodzaju męskiego lub żeńskiego, zależnie od rodzajnika i kontekstu, Mateusz mógł wykorzystać taki tekst w celu ukazania istnienia dwojga zwierząt: osła i oślicy. W istocie starożytne

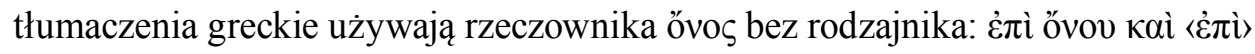



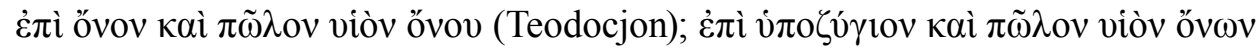
(Quinta). Wydaje się, iż Teodocjon mówi wprost o dwojgu zwierzętach, gdyż osiołka ( $\pi \tilde{\omega} \lambda \mathrm{ov})$ definiuje jako syna oślicy (viòv ővov), określając oślicę terminem ővos, którego używa także w pierwszym członie, nazywając tak, jak możemy przypuszczać, oślicę. Jest bowiem mało prawdopodobnym, aby użył tego samego rzeczownika ővo $\mathrm{w}$ jednym zdaniu dla określenia dwóch różnych płci dwojga zwierząt. W przypadku Quinty używa ona również ővos, nazywając w ten sposób oślicę. Żaden z powyższych czterech przekładów starożytnych, mimo znaczących podobieństw, nie odpowiada dokładnie w swej formie tekstualnej cytatowi w Mt 21,5. Stąd konkluzja M.J.J. Menkena, iż Mateusz mógł korzystać z niedostępnej dziś recenzji LXX, w której w pierwszym członie występował rzeczownik ővo $̧$ bez rodzajnika.

Pierwszym argumentem potwierdzającym tę tezę jest dokładna zgodność pierwszej części cytatu w Mt 21,5 z LXX:





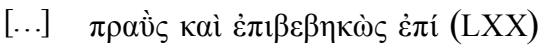

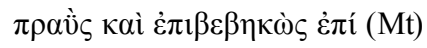

74 J. Dupont, „L'entrée messianique de Jésus à Jérusalem (Mt 21,1-17)”, AssS 37 (1965) 49. Podobnie Michel, , $\pi \tilde{\omega} \lambda \circ \varsigma^{\prime}, 960$.

75 BDF $\S 442,6$, przypis 18.

76 Zob. Mulzer, „Ein Esel, zwei Esel?”, 83. 
Powyższa pierwsza część cytatu w Mt 21,5 pochodziłaby zatem z LXX, źródłem zaś drugiej, dotyczącej zwierząt, byłaby niedostępna dziś rewizja LXX.

Kolejnym argumentem za powyższą tezą jest fakt, iż greckie ővos, które hipotetycznie byłoby obecne i to bez rodzajnika w rewizji LXX, służącej jako Mateuszowe Vorlage, może być interpretowane zarówno jako forma żeńska, jak i męska. Tymczasem hebrajskie חִ jest z reguły thumaczone w LXX przez formę męską. Mateuszowi zatem łatwiej było uzyskać swój tekst cytatu, bazując na tekście greckim ${ }^{77}$. Argument ten nie jest jednak przekonujący, gdyż w $2 \mathrm{Sm}$ 19,27 hebrajskie חִ̣ oznacza oślicę i jest tłumaczone w LXX przez żeńską formę $\tau \grave{n} v$ övov.

Teza M.J.J. Menkena ma cechy prawdopodobieństwa, jednak bez posiadania tekstu rzeczonej rewizji LXX pozostaje tylko hipotezą. Warto także pamiętać, iż Mateusz mógł otrzymać tekst swego cytatu z Za 9,9, tłumacząc jedynie $\mathrm{z}_{\text {hebrajskiego }}{ }^{78}$.

Nieznajomość zasady paralelizmu. W historii egzegezy Mt 21,5 dość chętnie uciekano się do wyjaśnienia sugerującego niezrozumienie przez Mateusza paralelizmu znajdującego się w Za 9,9. W świetle tej tezy Mateusz, nie rozumiejąc poprawnie zasad funkcjonowania hebrajskiego paralelizmu, jako mówiącego w Za 9,9 o jednym zwierzęciu, odwzorował dosłownie dwa człony tego paralelizmu, jako mówiące o dwojgu różnych zwierzętach. Konsekwencją tej tezy jest przekonanie, iż Mateusz nie opisał rzeczywistości historycznej, realnych dwojga zwierząt, ale pod wpływem błędnej egzegezy Za 9,9 dodał $\mathrm{w}$ swej narracji drugie zwierzę, nieistniejące w realnej historii ${ }^{79}$.

W tym samym kierunku idzie propozycja Karla Piepera, który uważa, iż niezrozumienie to nastąpiło nie tyle na etapie aramejskiego autora pierwotnej Ewangelii Mateusza, ile na etapie tłumaczenia $\mathrm{z}$ aramejskiego oryginału na znaną obecnie wersję grecką Ewangelii. W oryginale aramejskim występować miał jeden osioł (opisany za pomocą paralelizmu), a w błędnym (a więc dosłownym) tłumaczeniu greckim były już dwa osły ${ }^{80}$. Propozycja ta jest jednak nieprzekonująca. W tekście perykopy, poza kontrowersyjnym cytatem z Za 9,9, kilkakrotnie

77 Menken, „Context”, 115.

78 Przyznaje to sam Menken („Context”, 115), stwierdzając: „we cannot completely rule out the possibility that Matthew himself translated the Hebrew and arrived at the same result as the LXX translator".

79 S.V. McCasland, „Matthew Twists the Scriptures”, JBL 80 (1961) 145; D. Senior, The Catholic Study Bible (New York - Oxford: Oxford University Press 1990) ad loc. (,an awkward picture resulting from Matthew's misunderstanding of the prophecy”). Bartnicki („Tekst Za 9,9-10", 54) wylicza innych jeszcze komentatorów podzielających ten pogląd, wraz z referencjami bibliograficznymi: P. Dausch, K. Klostermann, T.H. Robinson, K. Staab, P. Bonnard, W. Grundmann.

80 K. Pieper, „Zum Einzug Jesu in Jerusalem”, BZ 11 (1913) 397-402. 
mowa jest o dwojgu zwierzętach, czy to wymieniając je z nazwy $(21,2.7)$, czy też odnosząc się do nich przez użycie zaimków w liczbie mnogiej $(21,3[\mathrm{x} 2] .7)$. Hipoteza Piepera sugeruje, iż tłumacz musiał dokonać w całej perykopie bardzo wielu zmian $z$ liczby pojedynczej na mnogą, po tym jak błędnie zinterpretował cytat z Za 9,9 jako mówiący o dwojgu zwierzętach. Konieczność tak wielu zmian w tekście greckim w stosunku do oryginału aramejskiego powinna jednak jasno dać do zrozumienia tłumaczowi, iż źle zinterpretował tekst wyroczni prorockiej. Bardziej logiczną jest zatem hipoteza mówiąca o autorze, który od początku pisał swą perykopę z myślą o dwojgu zwierzętach. Nadto, jak słusznie zauważył R. Bartnicki, hipoteza K. Piepera jest „,przypuszczeniem, którego nie można udowodnić, gdyż nie mamy oryginału aramejskiego ewangelii” [sic! $]^{81}$.

Przypuszczenie o niezrozumieniu zasad hebrajskiego paralelizmu przez Mateusza doprowadziło do zaskakującej konstatacji. Otóż pojawił się pogląd utrzymujący, iż ewangelista ten był chrześcijaninem o pogańskim pochodzeniu $^{82}$. Pogląd ten nie jest jednak uprawniony, gdyż zasada paralelizmu nie jest ograniczona tylko do literatury semickiej ${ }^{83}$.

Niezmienność tekstu biblijnego. David M. Stanley oraz Rudolf Pesch uważają, iż Mateusz wyznawał zasadę mówiącą o niezmienności tekstu biblijnego. Wyrazem tej zasady są słowa znajdujące się w samej Ewangelii Mateusza: „Dopóki niebo i ziemia nie przeminą, ani jedna jota, ani jedna kreska nie zmieni się w Prawie, aż się wszystko spełni” $(5,18)$. Zasada ta znalazła swój wyraz w przekonaniu o konieczności dosłownego tłumaczenia tekstu hebrajskiego. Mateusz miał zatem wybór pomiędzy niedosłownym i dosłownym tłumaczeniem Za 9,9. W pierwszym przypadku autor zachowałby zasadę paralelizmu synonimicznego i wskazałby na tylko jedno zwierzę, w drugim przypadku, tłumaczenia dosłownego, ignorowałby zasadę paralelizmu synonimicznego i wskazałby na dwoje zwierząt. Zdaniem komentatorów tylko w drugim przypadku autor pozostałby wierny zasadzie niezmienności tekstu hebrajskiego. Konsekwentnie w przypadku Mateuszowego opisu wjazdu Jezusa do Jerozolimy mamy do czynienia z wiernością tej właśnie zasadzie ${ }^{84}$.

81 Bartnicki, „Tekst Za 9,9-10”, 53.

82 G. Strecker, Der Weg der Gerechtigkeit. Untersuchung zur Theologie des Matthäus (FRLANT 82; Göttingen: Vandenhoeck \& Ruprecht 1962) 76: „sie ist schwerlich einem geborenen Juden oder Judenchristen zuzutrauen, bestätigt vielmehr unsere These von der unrabbinischen und unjüdischen, heidenchristlichen Herkunft des Evangelisten"; J.P. Meier, The Vision of Matthew. Christ, Church, and Morality in the First Gospel (Eugene, OR: Wipf and Stock 2004; pierwsze wyd. New York, NY: Paulist 1979) 17-25, zwłaszcza 21-22. Krytyka tej hipotezy w D.R. Bauer, Treasures New and Old. Recent Contributions to Matthean Studies (SBL.SS 1; Atlanta: Scholars 1996) 35.

83 Gnilka, Matthäusevangelium, 203.

84 D.M. Stanley, „Études matthéennes: L'entrée messianique à Jérusalem”, ScEs 6 (1954) 104-106; R. Pesch, „Eine alttestamentliche Ausführungsformel im Matthäus-Evangelium: Redaktionsgeschichtliche und exegetische Beobachtungen”, BZ 10 (1966) 245. 
R. Bartnicki odnosi się krytycznie do powyższej propozycji, gdyż tworzy ona fałszywy dylemat: dosłowne wypełnienie starotestamentalnych proroctw versus wierne odwzorowanie faktów z życia Jezusa. W opinii D.M. Stanley'a dla ewangelisty znaczenie ma jedynie dosłowne wypełnienie proroctw. Tymczasem Mateusz był zainteresowany zarówno opowiedzeniem faktów, jak i ukazaniem ich powiązania ze starotestamentalnymi zapowiedziami prorockimi. Obie rzeczywistości nie muszą się wzajemnie wykluczać ${ }^{85}$.

Paralelizm jako tekst prawny. David Instone-Brewer zaproponował nowe wyjaśnienie obecności dwóch osłów w opisie wjazdu Jezusa do Jerozolimy, które bazuje na intuicji wyrażonej wcześniej przez Kristera Stendahla. Stendahl zauważył, iż Mateusz różni się od tradycyjnej interpretacji rabinackiej, łączącej jednego osła z Mesjaszem (zob. b. Ber. 56B; b. Sanh. 98A). Zadaniem K. Stendahla jedynym racjonalnym wyjaśnieniem wprowadzenia przez Mateusza dwóch osłów w miejsce jednego mesjańskiego osła jest odwołanie się Mateusza do ówczesnej tradycji mówiącej o dwóch osłach w kontekście mesjańskim. Stendhal uważał także, iż wprowadzając dwa osły do swego tekstu, Mateusz był zaznajomiony $\mathrm{z}$ rabinackimi zasadami hermeneutycznymi ${ }^{86}$.

D. Instone-Brewer wychodzi od obserwacji, iż jest mało prawdopodobne aby wykształcony Żyd, za jakiego w powszechnym mniemaniu uchodzi autor pierwszej Ewangelii, mógł nie zrozumieć zasad funkcjonowania paralelizmu. Tym bardziej jest to trudne do przyjęcia w świetle obserwacji, iż w czasach Mateusza, a zatem w I w. po Chr., paralelizm był wciąż używany przez autorów żydowskich ${ }^{87}$. Brytyjski egzegeta uważa zatem, iż Mateusz oparł się na rabinackiej teorii funkcjonującej przed 70 r. przed Chr., w świetle której w Biblii nie ma miejsca na paralelizm ${ }^{88}$. Dla ówczesnych rabinów wszystkie pisma natchnione,

85 Bartnicki, „Das Zitat”, 165; Bartnicki, „Tekst Za 9,9-10”, 56-57.

86 K. Stendahl, The School of St. Matthew and Its Use of the Old Testament (ASNU 20; Lund: Gleerup 1954. ${ }^{2}$ 1968) 200: „The only reason for such a treatment of the O.T. text must be that Matthew knew a tradition, which spoke about two asses". Na innym miejscu (s. 119) Stendahl stwierdza: „It is surprising that in this way Matthew seems to overlook the significance of the M.T.'s parallelismus membrorum, but it is in no way a sign that he was unfamiliar with Jewish exegesis, but on the contrary gives evidence of his acquaintance with the hermeneutic methods of the rabbis".

87 G.B. Gray (The Forms of Hebrew Poetry. Considered with Special Reference to the Criticism and Interpretation of the Old Testament [LBS; New York: Ktav 1972] 10-31) wskazuje na obecność paralelizmu w Syryjskiej Apokalipsie Barucha (48,1-47), 4 Ezdrasza (8,20-30), qumrańskim Dokumencie Damasceńskim, Odach Salomona, Osiemnastu Błogosławieństwach, najwcześniejszych błogosławieństwach towarzyszących modlitwie Szema, Testamentach Dwunastu Patriarchów, Księdze Jubileuszy.

88 D. Instone-Brewer, Techniques and Assumptions in Jewish Exegesis before 70 CE (TSAJ 30; Tübingen: Mohr Siebeck 1992) 163-171; D. Instone-Brewer, „The Two Asses of Zechariah 9:9 in Matthew 21", TynB 54/1 (2003) 92-98. 
także te znajdujące się poza Torą, a więc w zbiorze Proroków i Pism, uważano za doskonałe prawo i traktowano jako teksty legislacyjne. Cechą charakterystyczną doskonałego prawa jest brak zbędnych treści. Konsekwentnie natchniony pisarz, w ich przekonaniu, nie mógł sobie pozwolić na niemające znaczenia (a więc zbędne) powtórzenia. Każde zdanie, w tym każdy człon paralelizmu, winien mieć swoje znaczenie i określać inną, nową prawdę i prawo ${ }^{89}$.

Jako przykład potwierdzający istnienie takiej teorii hermeneutycznej D. Instone-Brewer wskazuje na dyskusję między rabinami Bar Hé Hé i Hillelem, odnotowaną w m. Hag. 1,6 (b. Hag. 9b). Innym przykładem zaczerpniętym z literatury rabinackiej, potwierdzającym odrzucenie paralelizmu, jest zbiór tekstów egzegetycznych w $m$. Sanh. 10,3, datowanych na II w. po Chr. Interpretacja zawartych tam paralelizmów biblijnych wskazuje, iż niektórzy rabini wyjaśniali pierwszy człon paralelizmu jako odnoszący się do życia doczesnego, podczas gdy drugi człon miał nawiązywać do życia wiecznego ${ }^{90}$. Zdaniem D. Instone-Brewera potwierdzenie jego teorii znajduje się także w samej Ewangelii Mateusza. Otóż ewangelista $\mathrm{w}$ opisie męki Jezusa mówi zarówno o winie zmieszanym z żółcią (oĩvov $\mu \varepsilon \tau \grave{\alpha} \chi 0 \lambda \tilde{\eta} \varsigma-27,34)$, jak i o occie (ő os $_{-}$- 27,48). Łukasz i Jan mówią

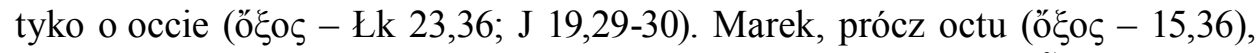

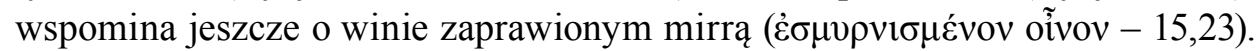
Mateusz zatem jest jedynym ewangelistą mówiącym o żółci i occie. Czyni tak, zdaniem D. Instone-Brewera, aby pozostać wiernym zasadzie nieistnienia paralelizmu synonimicznego. Ewangelista odwołuje się tutaj do Ps $69,22(68,22$ LXX), gdzie w pierwszym członie paralelizmu czytamy o dodaniu żółci ( $\chi 0 \lambda \eta ́)$ do pokarmu, a w drugim paralelizmie - octu (o $\xi \circ \varsigma)$ dla ugaszenia pragnienia. Dla Mateusza oba człony tegoż paralelizmu, jako mówiące o różnych rzeczach, musiałyby znaleźć swoje wypełnienie w męce Jezusa ${ }^{91}$.

Zdaniem D. Instone-Brewera powyższa zasada hermeneutyczna była ograniczona jedynie do określonej grupy rabinów w Palestynie, gdyż nie jest znana

89 Instone-Brewer, „The Two Asses”, 94: „the early rabbinic authorities [...] completely rejected any concept of synonymous parallelism, even in the Writings and the Prophets. If Scripture was written by the divine legislator, each line must carry equal weight, and represent a new truth or a new law".

90 Gray, Forms of Hebrew Poetry, 20.

91 Instone-Brewer, „The Two Asses”, 95. Podobny przykład rozbicia paralelizmu znajdujemy w przypadku użycia Ps 22,19 w J 19,23-24. Martin Mulzer („Ein Esel, zwei Esel?”, 85-86) uważa, iż użycie Ps 22,19 jako paralelizmu syntetycznego nie może być porównane z użyciem paralelizmu synonimicznego, jakim jest $\mathrm{Za} 9$,9. Autor ten uważa również, iż niewłaściwe jest porównywanie Mateuszowego użycia Za 9,9 z użyciem Rdz 49,11 w BerR 98,9 oraz reinterpretacji Rdz 15,9 TM w LXX. Wszystkie trzy powyższe przykłady podaje dla wyjaśnienia Mateuszowego użycia Za 9,9 Olaf Rölver, Christliche Existenz zwischen den Gerichten Gottes. Untersuchungen zur Eschatologie des Matthäusevangeliums (BBB 163; Göttingen: V\&R unipress - Bonn University Press 2010) 106. 
w Aleksandrii (np. u Filona) oraz nie występuje ona w Qumran. Teksty rabinackie, które komentują Za 9,9, zawsze mówią o jednym zwierzęciu, a zatem cezurę obowiązywania tej teorii D. Instone-Brewer wyznacza umownie na okres przed 70 r. przed Chr. Mateusz, mówiąc zatem o dwóch osłach, na których jechał Jezus, wskazuje na wypełnienie się proroctwa z Za 9,9, interpretowanego zgodnie $\mathrm{z}$ teorią pewnej rabinackiej grupy widzącej w każdym tekście natchnionym tekst prawny. Ewangelista Jan, cytujący Za 9,9 i mówiący o jednym ośle, idzie za interpretacją większościowego prądu w Judaizmie, który uznawał istnienie paralelizmu w Biblii, tak jak i w każdej innej literaturze. Zdaniem D. Instone-Brewera czytanie tekstu biblijnego na sposób każdej innej literatury jest rewolucją, która przychodzi dopiero w II w. po Chr. wraz z dwoma wielkimi postaciami - Rabbim Izmaelem oraz Rabbim Akiwą. Pierwszy z nich miał powiedzieć, iż „Pismo mówi językiem ludzi” (b. Ber. 31b; b. Ned 31a).

Stanowisko K. Stendahla spotkało się z krytyką G. Streckera i R. Bartnickiego. Uważają oni, iż rabini interpretowali paralelizm jedynie na potrzeby egzegezy alegorycznej, Mateusz natomiast daleki jest od alegorii i referuje jedynie fakty $^{92}$. Należy jednak zauważyć, iż Mateusz prócz faktów zawiera również teologię, wyrażaną za pomocą typologii, którą można potraktować jako formę alegorii. Nadto, zdaniem dwóch powyższych krytyków, Mateusz nie znał lub nie uwzględniał rabinackiej wykładni Za 9,9-10, łączącej ten tekst z postacią Mojżesza. W konsekwencji nie stosował rabinackich metod egzegetycznych ${ }^{93}$. Jak jednak wykażemy w dalszej części artykułu, Mt 21,1-11 odwołuje się do typologii Możesz - Mesjasz (Jezus).

Ocena. W świetle powyższej interpretacji w pierwszym członie paralelizmu z Za 9,9 Mateusz widział oślicę, w drugim zaś - oślę. Powyższa lektura Mateusza widziana jest jako złamanie zasady paralelizmu. Wyjaśnienie takie poddawane jest krytyce z następujących powodów. (1) Mateusz, jak pokazuje jego dzieło, doskonale zna język hebrajski. Sam cytat z Za 9,9 precyzyjnie odwzorowuje tekst hebrajski (lepiej niż czyni to LXX). Trudno zatem sugerować, aby Mateusz nie znał zasady paralelizmu wszechobecnej w poezji hebrajskiej, tym bardziej że w samej Ewangelii Mateusza cytowane są przynajmniej dwukrotne paralelizmy

92 Bartnicki, „Tekst Za 9,9-10”, 55: „W pismach rabinistycznych istniały rzeczywiście wypadki rozbijania tekstów zawierających paralelizm członków i wykładania każdej części oddzielnie, co czyniono wtedy, gdy chodziło o interpretację alegoryczną. Mateusz nie postępuje jednak według tej metody, gdyż nie idzie mu o tłumaczenie alegoryczne, lecz o zrelacjonowanie faktu".

93 Bartnicki, „Tekst Za 9,9-10”, 56: „W swej bowiem perykopie [Mt 21,1-11] nie uwzględnia typologii: Mojżesz - Mesjasz, występującej w egzegezie judaistycznej. Skoro więc nie zna wykładni rabinistyczno-mesjańskiej, to nie można przypuszczać, że stosuje egzegetyczne metody rabinów, polegające na rozbijaniu tekstów paralelnych i traktowaniu każdego członu jako oddzielnej frazy". Zob. Strecker, Der Weg, 72 i 76. 
ze ST $(8,17$; 11,17; zob. także 13,14-15; 15,8-9). (2) Tradycja rabinacka zawsze interpretowała tekst wyroczni Za 9,9 jako mówiący o jednym ośle ${ }^{94}$. Podobnie czyni J 12,15, cytując Za 9,9 i wspominając jednego osła. Jak zauważa R.H. Gundry, Mateusz adresujący swe dzieło do chrześcijan żydowskiego pochodzenia nie mógłby popełniać tak podstawowego błędu egzegetycznego, niweczącego jego argumentację $^{95}$. (3) R.H. Gundry przytacza jeszcze jeden argument spekulacyjny. Jeśli Mateusz chciałby zidentyfikować ővo $\varsigma$ w cytacie $(21,5)$ z oślicą występującą w narracji (óvo $\varsigma$ - 21,2.7), wówczas powinien przetłumaczyć paralelizm w następujący sposób: „na oślicy (ővos) i na osiołku, źrebięciu oślicy (ővos)”. Powinien zatem powtórzyć rzeczownik ővo $\mathrm{w}$ drugim członie paralelizmu, tak by powiązać go z tym samym rzeczownikiem w pierwszym członie paralelizmu. Byłoby to także w zgodzie z praktyką translacyjną obecną w LXX, gdzie rzeczownik אָּז z drugiego członu paralelizmu jest zazwyczaj tłumaczony przez ővos. (Przypomnijmy, iż takie tłumaczenie znajdujemy u Teodocjona). Tymczasem Mateusz tłumaczy oślicę w drugiej części paralelizmu, używając

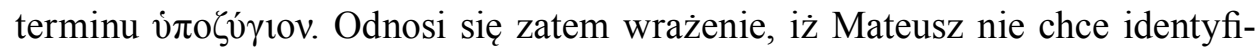
kować zwierzęcia (ővos) z pierwszego członu paralelizmu z oślicą ( występującą w drugim członie. Konsekwentnie, Mateusz nie chce identyfikować oślicy ze swej narracji (ővo - 21,2.7) ze zwierzęciem z pierwszego członu cytatu (ővos $-21,5)^{96}$.

\subsubsection{Mateusz zachowuje zasadę paralelizmu synonimicznego i widzi w Za 9,9 dwa osły}

Uznając nawet istnienie paralelizmu synonimicznego w Za 9,9 mówiącego o jednym ośle, dosłownie czytany hebrajski tekst wyroczni Za 9,9 rzeczywiście wspomina o dwojgu zwierzętach, gdyż oślę w drugim członie paralelizmu jest zdefiniowane przez relację do swej matki. Tekst zatem wzmiankuje tego samego, jednego osła w pierwszym i drugim członie (przy użyciu trzech terminów oraz drugie zwierzę, oślicę - tylko w drugim członie (אן ,עיר ,חמור (אתון (ביר ${ }^{97}$. Innymi

94 Zob. b.Ber 56b-57a = b.San. 99a; b. San. 98a; Midrasz Rabba Rdz 75,6; 98,9; 99,8; Midrasz Rabba Wj 30,4; Midrasz Rabba Pwt 4,11; Midrasz Rabba Pnp 1,29; Midrasz Rabba Koh 1,28.

95 R.H. Gundry, The Use of the Old Testament in St. Matthew's Gospel with Special Reference to the Messianic Hope (NT.S 18; Leiden: Brill 1967) 198: ,it is just as doubtful that Mt would have deliberately perpetrated such an obvious error in writing to evangelize Jews, who could have easily detected the error - and this in the face of rabbinic tradition, which knew only one animal in Zech 9:9, and seemingly against the rest of the gospel tradition".

96 Gundry, The Use of the Old Testament, 198.

97 W tekście („na źrebięciu synu oślic”) występuje liczba mnoga („oślic”), która opisuje jednak przedmiot pojedynczy. Zob. GKC $\$ 124 o$. Liczba mnoga pełni tutaj funkcję uogólnienia, określając gatunek zwierzęcia. Zob. B.K. Waltke - M. O'Connor, An Introduction to Biblical Hebrew Syntax (Winona Lake, IN: Eisenbrauns 1990) §7.4.3a. 
słowy, proroctwo opisuje jazdę przyszłego mesjańskiego króla na jednym ośle, choć oślę to opisane jest poprzez swą relację do oślicy. Ten sam fenomen obecny jest w tekście greckim Za 9,9 cytowanym w Mt 21,5. Podsumowując, narracja Mateuszowa mówi o dwojgu zwierzętach, oślicy i jej źrebięciu $(21,2.7)$. Nadto Mateuszowy cytat z Zachariasza, zgodnie z zasadami paralelizmu synonimicznego, wskazuje na jedno oślę, jednak - jak twierdzi R.H. Gundry - jest ono tak młode, iż występuje razem z oślicą (21,5). Motywem obecności oślicy w narracji i cytacie jest zatem chęć podkreślenia młodości osiołka, jego nieujeżdżenie, o którym wspominają pozostali dwaj synoptycy ${ }^{98}$.

\subsubsection{Mateusz zachowuje zasadę paralelizmu synonimicznego i widzi w Za 9,9 jednego osła}

Roman Bartnicki zaproponował rozwiązanie odwołujące się do pracy redakcyjnej ewangelisty. Zdaniem warszawskiego egzegety cytat z Zachariasza w Mt 21,5

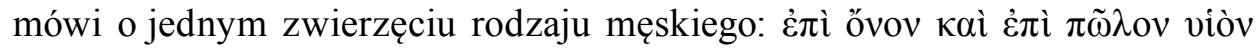


rodzaj, stąd może być rodzaju męskiego lub żeńskiego. Rzeczownik $\pi \tilde{\omega} \lambda$ o jest rodzaju męskiego. W wersecie 7. występuje już jednak dwoje zwierząt ( $\tau \grave{v} v$ övov


żeńskim. Podobne rozróżnienie dwojga zwierząt dwóch rodzajów występuje w kontekście poprzedzającym (w. 2). Zdaniem R. Bartnickiego redaktor połączył w jednym opowiadaniu dwie tradycje bez ich uzgodnienia. Pierwsza bazowała na cytacie z Za 9,9 i mówiła o jednym ośle rodzaju męskiego, choć z użyciem dwóch różnych rzeczowników na określenie tego samego zwierzęcia (w. 5). Druga tradycja mówiąca o znalezieniu dwojga zwierząt dwóch różnych płci używała do ich opisu dwóch różnych terminów (w. 2.7). Autor hipotezy stwierdza: „Samo opowiadanie o znalezieniu zwierząt może wywodzić się z jednej tradycji, w której była mowa o oślęciu i oślicy, natomiast cytat z Zachariasza - z innej, zawierającej wzmiankę o jednym zwierzęciu oznaczonym dwoma terminami. Ostatni redaktor Ewangelii nie zatroszczył się o to, by te dwie różne tradycje uzgodnić ze sobą"99. R. Bartnicki utrzymuje, iż uczniowie przyprowadzili do Jezusa dwoje zwierząt, ale Jezus wjechał do Jerozolimy tylko na jednym. Wprowadzenie cytatu z Za 9,9, mówiącego o jednym zwierzęciu, doskonale korespondowało $\mathrm{z}$ historycznym

98 Gundry, The Use of the Old Testament, 199.

99 Bartnicki, „Tekst Za 9,9-10”, 57. Teza R. Bartnickiego o połączeniu dwóch różnych tradycji może być potwierdzona przez tezę o redakcyjnym charakterze cytatu z Za 9,9. M.J.J. Menken („Context”, 107) stwierdza, iż cytat został dodany przez redaktora do oryginalnego opowiadania: "It is obvious that the quotation has been inserted at the level of Matthew's redaction: it interrupts the flow of the story taken over from Mark". 
wjazdem Jezusa na jednym ośle. Pozostałe Ewangelie kanoniczne nie wspominają o drugim zwierzęciu, gdyż (1) Jezus wjechał do Jerozolimy tylko na jednym ośle oraz (2) cytat z Za 9,9 mówi także o jednym zwierzęciu. Nacisk Mateusza położony na obecności dwojga zwierząt wynika zatem z (1) historycznych faktów (przyprowadzono dwoje zwierząt i drugi osioł towarzyszył pierwszemu w czasie całego wjazdu) oraz (2) chęci ukazania dosłownego wypełnienia się proroctwa Za 9,9 (tak jak w cytacie król wjeżdża na jednym ośle, tak i historyczny Jezus wjechał do Jerozolimy na jednym ośle). Hipoteza Bartnickiego bazuje zatem na dwuznaczności rodzajowej rzeczownika ővo $̧$ w Mt 21,5, który w oryginalnym kontekście Księgi Zachariasza był interpretowany w rodzaju męskim, natomiast w kontekście Ewangelii Mateusza - błędnie - w rodzaju żeńskim ${ }^{100}$.

R. Bartnicki dostrzega zarzut, jaki można wysunąć przeciwko jego hipotezie: skoro w najbliższym kontekście $(21,2.7)$ rzeczownik ővo jest użyty w rodzaju żeńskim, to także w 21,5 powinien być rozumiany w rodzaju żeńskim. Autor hipotezy odpiera to zastrzeżenie, twierdząc, iż Ewangelie zawierają teksty z różnych tradycji ${ }^{101}$. Trudno jednak uznać za celową i intencjonalną zaproponowaną grę znaczeń: ővo $\mathrm{w}$ rodzaju żeńskim w wersecie poprzedzającym (w. 2), by następnie przejść do ővos w rodzaju męskim (w. 5) i znów powrócić do ővo w rodzaju żeńskim w kontekście następującym (w. 7). Skoro w wersecie 4. czytamy o wypełnieniu się zapowiedzi prorockiej, a ta odnosi się do przyprowadzenia ővo $̧$ w rodzaju żeńskim (w. 2), to można słusznie oczekiwać takiego samego rodzaju tego rzeczownika w proroctwie w w. 5. Czy autor pozwoliłby sobie na nielogiczność użycia tego samego rzeczownika w dwóch różnych rodzajach? A może jest tutaj subtelna gra znaczeń: pozorna zgodność rodzaju w trzech wystąpieniach (potwierdzająca jedność narracji), a z drugiej strony możliwość rozumienia środkowego wystąpienia ővo $w$ cytacie w rodzaju męskim (odpowiadająca przesłaniu tekstu hebrajskiego i będąca ukłonem w kierunku wszystkich czytelników znających hebrajskie Vorlage)? ${ }^{102}$

\subsubsection{Mateusz rozumie Za 9,9 jako paralelizm syntaktyczny i widzi tam dwa osły}

Istnieje także możliwość, iż Mateusz zinterpretował tekst Za 9,9 jako paralelizm syntaktyczny, a zatem mówiący o dwojgu zwierzętach. Mateuszowy tekst

100 Bartnicki, „Das Zitat”, 161-166; Bartnicki, „Tekst Za 9,9-10”, 57.

101 Bartnicki, „Tekst Za 9,9-10”, 57.

102 W. Weren (,Jesus’ Entry into Jerusalem”, 131) odrzuca rozwiązanie R. Bartnickiego, twierdząc, iż Mateuszowa narracja - poza cytatem Za 9,9 i Markiem - nie wskazuje na odwoływanie się do innych tradycji. Autor ten również zauważa, iż R. Bartnicki nie przedstawia żadnej próby wydzielenia tekstu przynależnego do starszej tradycji mającej mówić o dwóch osłach. 


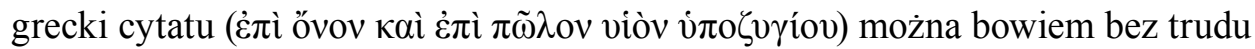
zinterpretować jako taki paralelizm. Pierwszy rzeczownik, ővov, może oznaczać zwierzę rodzaju żeńskiego i może odnosić się do oślicy. Drugi rzeczownik, $\pi \tilde{\omega} \lambda$ ov, odnosiłby się do męskiego źrebięcia. Podwojenie przyimka غ̇лí wspiera taką interpretację. Wyjaśnienie to jest także zgodne z bezpośrednim kontekstem cytatu, który mówi o oślicy (określonej zawsze przez rzeczownik ővo $)$ ) oraz źrebięciu (określonym zawsze przez termin $\pi \tilde{\omega} \lambda$ os) (zob. 21,2.7). W narracji Mateusza ővo, określający oślicę, w obu przypadkach $(21,2.7)$ występuje na pierwszym miejscu, co może sugerować, iż również w cytacie termin ten, także znajdując się na pierwszym miejscu, określa oślicę. Takie odczytanie cytatu byłoby również zgodne z Mateuszowym naciskiem na dosłowne i bezpośrednie wypełnienie się starotestamentalnych przepowiedni ${ }^{103}$.

Próba odczytania Za 9,9 jako tekstu mówiącego o dwóch różnych osłach może być usprawiedliwiona z punktu widzenia semantycznego. Otóż zarów-


pozwalają na identyfikację zwierzęcia w pierwszym członie paralelizmu jako oślicy. Odnośnie do pola semantycznego terminu חמור, jak wspominaliśmy wcześniej, występuje on zarówno w rodzaju żeńskim, jak i męskim. Dla przykładu w 2 Sm 19,27 termin ten oznacza samicę i LXX stosuje tutaj żeńską

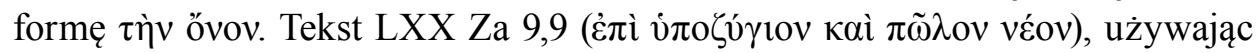

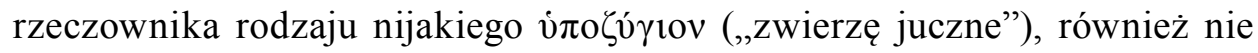
wyklucza możliwości widzenia w pierwszym członie paralelizmu oślicy. W LXX

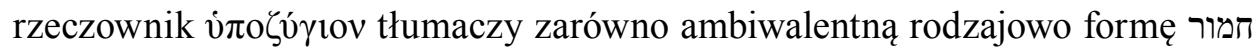
(Sdz 19,10 A), jak i żeńską (Sdz 5,10 A). Rzeczownik ővos, użyty przez Mt 21,5, również występuje zarówno w rodzaju męskim (Ne 3,15; Łk 13,15), jak i żeńskim (2 Sm 17,23; 19,27; Mt 21,2.7). Rodzaj ővoৎ w cytacie w Mt 21,5

103 Weren, „Jesus’ Entry into Jerusalem”, 131. Za odczytaniem przez Mateusza w Za 9,9 paralelizmu syntaktycznego opowiada się także Martin Mulzer („Ein Esel, zwei Esel?”, 87). Jego zdaniem tekst hebrajski wyroczni dostarcza semantycznych podstaw do mówienia o dwojgu rożnych

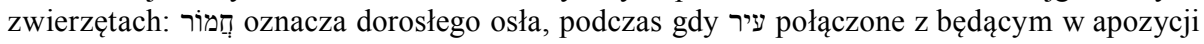
zwrotem בן־אתנות - męskiego młodego osła. To samo semantyczne rozróżnienie może być


powyższa propozycja interpretacyjna jest wsparta przez Rdz 49,11, gdzie עיר - młody osioł jest zestawiony w paralelizmie synonimicznym z בני אתנו - synem oślicy. Tekst Rdz 49,11, używając różnych terminów, mówi o jednym młodym ośle. Także LXX używa tego samego rzeczownika $\pi \tilde{\omega} \lambda$ ov w obu członach paralelizmu Rdz 49,11 ( òv $\pi \tilde{\omega} \lambda$ ov // $\tau$ òv $\pi \tilde{\omega} \lambda$ ov $\tau \tilde{\eta} \varsigma$ övov), wskazując, iż chodzi tylko o jednego osła. Terminy w Rdz 49,11 są identyczne z drugim członem paralelizmu w Za 9,9 opisującego młodego osła. Mulzer sugeruje zatem, iż tekst hebrajski Za 9,9 wskazuje na istnienie dwóch osłów: dorosłego osła oraz młodego osiołka. Argumentacja Mulzera, przynajmniej w części odwołującej się do tekstu hebrajskiego, jest jednak chybiona w świetle dokładnej analizy semantycznej terminów hebrajskich znajdującej się w Way, Donkeys, 162-170. Odniesienie do wieku zwierząt nie występuje w terminach hebrajskich. Co do greckiej części interpretacji Mulzera, tekst grecki (LXX oraz Mt 21,5) pozwala widzieć dwa osły. 
ze względu na brak rodzajnika jest nieokreślony. Konsekwentnie zatem jego rodzaj jest zdefiniowany przez najbliższy kontekst, który dwukrotnie używa rzeczownika ővoৎ w rodzaju żeńskim. Znaczenie drugiej części paralelizmu


szącego się do osła płci męskiej, nie pozostawia wątpliwości. W tekście greckim mówi się także o jego młodości poprzez użycie terminów véos (Za) oraz $\pi \tilde{\omega} \lambda$ os $(\mathrm{Za}, \mathrm{Mt})^{104}$. Koronnym argumentem za możliwością rozumienia tekstu Za 9,9 w Mt 21,5 jako mówiącego o dwojgu zwierzętach jest bez wątpienia

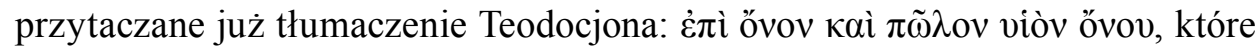
możemy przełożyć jako „na oślicy i na źrebięciu synu oślicy”. Teodocjon używa zatem terminu ővoৎ dwukrotnie, przy czym jego niezaprzeczalny żeński rodzaj $\mathrm{w}$ drugim członie sugeruje ten sam żeński rodzaj w pierwszym członie. Warto zauważyć, iż Teodocjon identyfikowany jest z Jonatanem ben 'Uzzielem, który dokonał recenzji Septuaginty w połowie I w. po Chr. ${ }^{105}$ Należy zatem podkreślić zbieżność czasową redakcji Ewangelii Mateusza (II poł. I w. po Chr.) oraz powstania tejże rewizji LXX. W obu przypadkach mielibyśmy do czynienia z tą samą egzegezą Za 9,9, która widzi w tym proroctwie dwoje zwierząt. Mateusz, stosując jednak różne terminy dla określenia samicy w pierwszym (ővo $\varsigma$ )

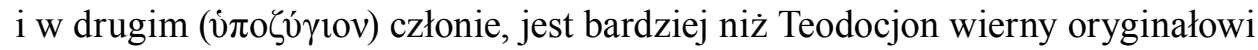
hebrajskiemu, który również używa dwóch różnych wyrażeń dla oznaczenia zwierzęcia (w pierwszym - חמור i w d אמון - Oba pojęcia hebrajskie są dwuznaczne rodzajowo, stąd też również Mateusz zastosował korespondujące

104 Na temat semantyki terminu $\pi \tilde{\omega} \lambda$ o $̧$ zob. W. Bauer, „The Colt of Palm Sunday (Der Palmesel)”, $J B L 72$ (1953) 220-229. Autor ten konkluduje, iż termin ten początkowo oznaczał młode zwierzę (różnych gatunków), następnie został ograniczony do młodego konia, by ostatecznie oznaczać wyłącznie konia w ogólności. Stąd też jeśli termin ten występuje samodzielnie, oznacza konia, jeśli natomiast razem z innym dookreśleniem gatunkowym (jak w Mt 21,5), wówczas oznacza młode zwierzę tego gatunku. W przypadku Za 9,9 król jedzie „na ośle, i to na nowym (nieujeżdżonym) młodym ośle” (,riding on a donkey, and at that on a new [i.e. unused, never before ridden] young animal"). W narracji Marka i Łukasza, gdzie termin $\pi \tilde{\omega} \lambda$ o $\varsigma$ występuje samodzielnie, czytelnik interpretował zwierzę, na którym wjeżdżał Jezus, jako konia. Dopiero Mateusz, chcąc powiązać narrację Marka z wypełnieniem się starotestamentalnych Pism, odnalazł Markowego $\pi \tilde{\omega} \lambda$ o $\varsigma \mathrm{w}$ Zachariaszowym $\pi \tilde{\omega} \lambda \mathrm{\jmath}$ (gdzie termin ten był połączony z osłem) i stworzył młodego osła. Tradycję Mateuszową miałby później przejąć czwarta Ewangelia (J 12,14.15). Teoria Bauera jest oczywiście hipotezą. Nie przekonuje ona zwłaszcza w przypadku Za 9,9 LXX: Jeśli $\pi \tilde{\omega} \lambda$ o oznacza młode zwierzę, a konkretnie młodego osła, dlaczego dodany jest jeszcze przymiotnik véoৎ („,młody”)? Bauer zarzuca również Mt i J fałszowanie historycznych faktów, na co trudno się bezkrytycznie zgodzić. Nadto narracja Marka o wjeździe Jezusa do Jerozolimy bazuje na Rdz 49,11, gdzie wprost wspomina się o ośle. Ponadto rzeczownik $\pi \tilde{\omega} \lambda$ o występujący tylko 7 razy w LXX, w 6 przypadkach tłumaczy osła ogiera - עיר (Rdz 32,16; 49,11; Sdz 10,4; 12,14; Za 9,9) lub osła czystej krwi - בני אתנו (Rdz 49,11), a w jednym kozicę (Prz 5,19).

105 D. Barthélemy, Les devanciers d'Aquila. Première publication intégrale du texte des fragments du Dodécaprophéton trouvés dans le désert de Juda, précédée d'une étude sur les traductions et recensions grecques de la Bible réalisées au premier siècle de notre ère sous l'influence du rabbinat palestinien (VT.S 10; Leiden: Brill 1963) 144-157. 
z nimi dwa terminy, które są również nieokreślone rodzajowo. Mateusz okazuje się zatem wiernym tłumaczem tekstu hebrajskiego.

\subsubsection{Cytat kreujący rzeczywistość czy też rzeczywistość przywołująca cytat?}

Cytowanie przez Mateusza wyroczni Za 9,9 kreuje dwie możliwości interpretacyjne określające relację przesłania cytatu do historyczności wydarzenia. Część komentatorów uważa, iż wspominający o dwóch osłach cytat sprowokował dodanie drugiego osła do narracji. Inni egzegeci natomiast sugerują, że cytat (mówiący o dwóch osłach) wiernie opisuje historyczne wydarzenie, w którym były obecne dwa osły. W skrajnym przypadku historyczne realia (w których występowały dwa osły) wymogły przeformułowanie cytatu (oryginalnie mówiącego o jednym ośle) tak, by mówił o dwóch osłach. Wayne Coppins określa te dwie tradycje interpretacyjne jako "history conformed to Scripture interpretation” (interpretacja, w której historia podporządkowana jest Pismu) oraz „Scripture conformed to history" (Pismo podporządkowane historii) ${ }^{106}$. Poniżej omówimy szerzej oba stanowiska.

Wielu komentatorów spekuluje, iż historycznie Jezus wjeżdżał do Jerozolimy jedynie na jednym zwierzęciu, drugie zwierzę natomiast zostało dodane (w sensie sfabrykowane) w narracji przez ewangelistę ze względu na odniesienie do dosłownie rozumianego proroctwa Za 9,9. Ewangelista mówi zatem o dwojgu zwierzętach z powodu chęci wykazania jak najbardziej dosłownego wypełnienia się proroctwa Za 9,9 $9^{107}$. W. Coppins przedstawia cztery argumenty za powyższą hipotezą: (1) Pozostałe trzy Ewangelie kanoniczne mówią o jednym ośle. Stąd wydaje się bardziej prawdopodobnym, iż realny obraz sytuacji został przedstawiony przez większą liczbę narracji. (2) Mateusz mógł dokonać zdublowania osłów w zgodzie ze swą zasadniczą tendencją do dublowania postaci $(8,28 ; 9,27$; 20,30). (3) Podwojenie osłów może być wynikiem Mateuszowej egzegezy Za 9,9, w świetle której w paralelizmie widział dwoje zwierząt. Jeśli zatem forma Za 9,9 w hermeneutyce Mateusza i jego współczesnych mówiła o dwojgu zwierzętach, ewangelista mógł dostosować opis wydarzenia do przesłania cytatu.

106 W. Coppins, „Sitting on Two Asses? Second Thoughts on the Two-Animal Interpretation of Matthew 21:7”, TynB 63/2 (2012) 276-281.

107 Menken, „Context”, 110: „Matthew has adjusted the narrative to the quotation”; Gundry, The Use of the Old Testament, 197: ,Zech 9:9 in Mt 21:5 is most universally considered an instance of prophecy creating tradition". E. Haenchen (Der Weg Jesu. Eine Erklärung des MarkusEvangeliums und der kanonischen Parallelen [Sammlung Töpelmann II,6; Berlin: Töpelmann 1966] 377) w tym samym duchu spekuluje, iż ewangelista wcale się nie zastanawiał, jak technicznie była możliwa jazda na dwóch osłach. Wychodził on bowiem z założenia, iż skoro Bóg zapowiedział takie wydarzenie (Za 9,9), to rzeczywiście tak się musiało stać. 
(4) Tendencja Mateusza do ukazywania dosłownego wypełniania się zapowiedzi starotestamentalnych potwierdzona jest na innych miejscach pierwszej Ewangelii. Dla przykładu, nieokreślona suma pieniędzy z Mk 14,11 w narracji Mateusza $(26,15)$ staje się trzydziestoma srebrnikami pod wpływem Za 11,13 cytowanego w Mt 27,9-10. Inne przykłady znajdziemy w 4,13.15 (pokolenia Zabulona i Neftalego) oraz 27,7.10 (Pole Garncarza) ${ }^{108}$. Żaden z powyższych czterech argumentów nie jest jednak rozstrzygający, a tym samym hipoteza nie jest w sposób przekonujący potwierdzona.

Możliwa jest również hipoteza odwrotna, a mianowicie realna obecność dwojga zwierząt $\mathrm{w}$ historycznym wydarzeniu sprowokowała zacytowanie proroctwa wzmiankującego dwoje zwierzą ${ }^{109}$. Na taki przebieg wydarzeń wskazuje paralelna narracja Janowa: Jezus dosiada osła, a dopiero później uczniowie przypominają sobie Za 9,9 i łączą to wydarzenie z tekstem ST (J 12,16). W przypadku narracji Janowej to nie Za 9,9 stoi za kształtem narracji, ale wydarzenie historyczne kształtuje narrację i przywołuje tekst Za 9,9. Wracając do relacji Mateusza, tekst proroctwa wzmiankujący dwoje zwierząt mógł doskonale pokrywać się z historycznym wydarzeniem, czyli faktem przyprowadzenia do Jezusa młodego źrebaka i jego matki, oślicy, jako nierozdzielnego zespołu dwojga zwierząt. Jezus mógł zatem w rzeczywistości jechać na jednym zwierzęciu, któremu w naturalny sposób towarzyszyło drugie zwierzę. Nie można również wykluczyć, iż Jezus świadomie zażądał przyprowadzenia dwojga zwierząt celem literalnego wypełnienia mesjańskiego proroctwa ${ }^{110}$. Wiele czynów Jezusa ma bowiem znamiona działań mających na celu wypełnienie starotestamentalnych proroctw ${ }^{111}$. Wobec powyższego, nie ma konieczności przyjmowania

108 Coppins, „Sitting on Two Asses?”, 280-281, 289.

109 France, Matthew (2007), 778: ,aware that two animals had been present, he [Matthew] enjoyed the fact that the wording of Zechariah's oracle can be read as including both mother and foal, and so mentioned then both".

110 H. Fowler (The Gospel of Matthew [Bible Study Textbooks Series; Joplin, MO: College Press 1985] IV, 29) twierdzi, iż Jezus wyraźnie zażądał przyprowadzenia dwojga zwierząt, z intencją ukazania dosłownego wypełnienia proroctwa Zachariasza: „By re-enacting everything in Zecharia's prophecy down to the fine detail of including the seemingly unnecessary she-ass in the picture, Jesus intended to focus public attention to the prophecy".

111 Na temat intencjonalnego działania Jezusa wypełniającego starotestamentowe proroctwa zob. C.A. Evans, ,Jesus and Zechariah's Messianic Hope”, Authenticating the Activities of Jesus (red. B.D. Chilton - C.A. Evans) (NTTS 28/2; Leiden - Boston, MA - Köln: Brill 1999) 388: „Given the observation that other Jewish figures of the late second Temple period acted out scriptural patterns and oracles, we should resist the 'critical' impulse to assign scriptural correlations in the Gospel narratives to the theological and literary creativity of the evangelists (or tradents before them). In my judgment it is probable that Jesus' behaviour while in Jerusalem was guided by elements and themes in Zechariah”. Zob. również B.F. Meyer, „Appointed Deed, Appointed Doer: Jesus and the Scriptures", Authenticating the Activities of Jesus (red. B.D. Chilton C.A. Evans) (NTTS 28/2; Leiden - Boston, MA - Köln: Brill 1999) 172-173, 174: „Jesus, in the consciousness of election to a climactic and definitive mission to Israel, sought and found 
hipotezy, iż Mateusz sfabrykował fakt istnienia drugiego osła celem ukazania dosłownego wypełnienia się proroctwa z Za 9,9. Fakt, iż pozostałe Ewangelie kanoniczne wspominają jedynie o jednym ośle, nie przeczy powyższej tezie, gdyż pozostali ewangeliści oddali istotę rzeczy - jaką był pokorny wjazd Jezusa na jednym ośle do Jerozolimy - bez wchodzenia w detale odnośnie do sposobu tego wjazdu, czyli towarzyszenia drugiego zwierzęcia. Ze względu na zwięzłość narracji Marek i Łukasz nie cytują nawet Za 9,9, podczas gdy Jan

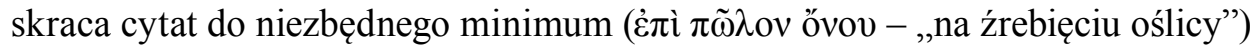
i zwięźle referuje całe wydarzenie jednym zdaniem: sam Jezus znajduje (czasownik kauzatywny) osiołka i wsiada na niego. W relacji Jana nie ma również mowy o posłaniu dwóch uczniów po osły (osła) czy o nałożeniu nań szat ${ }^{112}$.

\subsubsection{Podsumowanie Mateuszowego użycia Za 9,9}

W świetle powyższego wyjaśnienia możemy wyróżnić kilka motywów wprowadzenia cytatu z Za 9,9 do narracji Mateusza. (1) Cytat wskazuje na wypełnienie się mesjańskiej zapowiedzi o wjeździe przyszłego potomka Dawida na osiołku do Jerozolimy. Czyn Jezusa ma walor gestu symbolicznego nawiązującego do starotestamentalnego proroctwa. Poprzez symboliczny gest wykonany przez Jezusa oraz cytowanie tekstu proroctwa przez ewangelistę Jezus jest identyfikowany jako obiecany mesjański król. W tym przypadku nie ma znaczenia, czy Jezus wjeżdża na jednym czy na dwóch osłach, gdyż w obu przypadkach odwołanie do Za 9,9 jest ewidentne poprzez wspólne elementy cytatu i symbolicznego gestu: król Dawidowy - wjazd do Jerozolimy - osioł. Sytuacja zmieni się jednak, jeśli uznamy istnienie jednej powszechnie przyjętej wykładni Za 9,9 mówiącej o dwóch osłach. Wówczas element użycia dwojga zwierząt będzie także wskazywał na wypełnienie się proroctwa (jednak jeszcze bardziej dosłowne) i będzie podkreślał królewskość i mesjańskość Jezusa ${ }^{113}$. (2) Cytując Za 9,9, Mateusz przywołuje cały kontekst cytatu Za 9-14, który prezentuje specyficzny typ mesjasza (króla pokoju, panującego na wieki i nad całym światem) oraz wyznacza czas eschatonu (nawrócenie wszystkich narodów i ich zgromadzenie

in the Scriptures the specifications of God's eschatological deed and the specifications of his own role as the chosen instrumental doer of that deed [...] Jesus is seen as intent on listening to the Scriptures for the orientation of his life and mission".

112 Więcej na temat Janowego użycia Za 9,9 zob. A. Kubiś, The Book of Zechariah in the Gospel of John (Études Biblique. Nouvelle Série 64; Pendé: Gabalda et Cie 2012) 27-114.

113 Por. Coppins, „Sitting on Two Asses”, 287-288: ,it seems to me that speaking of Jesus sitting on two animals only strengthens the unusual and majestic aspect of the situation. [...] In my judgment, this suggestive reading of the text represents a plausible development of a motif that is certainly emphasized in the text, namely the evangelist's clear intention to present Jesus as king (21:5)". 
na Górze Syjon w celu kultu jednego Boga). (3) Wspomnienie o oślicy, znajdujące się w pierwszym członie paralelizmu (M. Mulzer) lub w drugim członie paralelizmu (R.H. Gundry), może odpowiadać historycznej rzeczywistości. Jeśli osiołek był młody, oślica mogła towarzyszyć osiołkowi w czasie wjazdu. W odróżnieniu od pozostałych ewangelistów (piszących o jednym młodym osiołku) Mateusz, wspominając dwa osły, opisywałby realia historyczne bardziej wiernie niż pozostali ewangeliści, gdyż obecność matki przy źrebięciu jest rzeczą naturalną i oczekiwaną. Cytat zatem doskonale ilustrował realia historyczne wjazdu Jezusa do Jerozolimy. (4) Mateusz nie wspomina detalu (obecnego w Mk i Łk) mówiącego o tym, że osiołka nikt nie dosiadał. Cytat wzmiankujący oślicę mógłby zatem wskazywać również na młodość osiołka, który jest wciąż jeszcze określany przez swą relację do matki. Temu samemu celowi, ukazaniu młodości osiołka, służyłoby również wzmiankowanie oślicy w referowaniu wydarzenia w 21,2.7 $7^{114}$. (5) W naszej opinii istotniejsza niż użycie jednego terminu, np.


„sprawiedliwy” oraz „zwycięski”, a pozostawienie „łagodny” - która wskazuje na łagodność jako główną charakterystykę Jezusa jako mesjańskiego króla.

\subsection{Interpretacje typologiczne}

Typologia Mojżeszowa. Źródła rabinackie dostarczają wielu dowodów na istnienie tradycji interpretowania postaci przyszłego Mesjasza przez pryzmat słów i dokonań Mojżesza. Kluczowym jest zadanie Rabina Berakiasza odnoszące się do Mojżesza i przyszłego Mesjasza: „Jakim był pierwszy odkupiciel, takim będzie również ostatni”" ${ }^{\prime 15}$. Ślady Mojżeszowej typologii mesjańskiej, zwłaszcza widzenia w Jezusie wypełnienia Mojżeszowego proroctwa z Pwt 18,15.18, spotkamy w NT (zob. Dz 3,17-26; J 1,43-51; 4,19.29; 6,14-15) ${ }^{116}$. Przyszłe zbawienie, które miało się dokonać za sprawą działalności Mesjasza, nowego Mojżesza, widziane było przez autorów NT jako nowy exodus, powtórzenie cudu wyjścia z niewoli egipskiej pod wodzą Mojżesza. Szczególnie jasno typologię Mojżeszową

114 Stendahl, The School of St. Matthew, 200; B. Lindars, New Testament Apologetics. The Doctrinal Significance of the Old Testament Quotations (London: SCM 1961) 114; C.A. Evans, Matthew (NCBC; Cambridge: Cambridge University Press 2012) 359.

115 Midrasz Rabba Koh 1,28. Zob. także Tanhuma 'Ekeb 7b; Midrasz Rabba Wj 1,26; Midrasz Rabba Rut 5,6; Tg Pnp 4,5.

116 D.C. Allison, The New Moses. A Matthean Typology (Minneapolis, MN: Augsburg Fortress 1993) 85-90. Więcej na temat mesjańskiego rozumienia Pwt 18,9-22 zob. M. Baraniak, Prorok jak Mojżesz (Pwt 18,9-22). Hermeneutyka prawa o urzędzie proroka w Izraelu (Rozprawy i Studia Biblijne 19; Warszawa: Vocatio 2005). 
wykorzystuje Mateusz $^{117}$. Wobec powyższego amerykańscy egzegeci William D. Davies and Dale C. Allison interpretują Mateuszowy opis triumfalnego wjazdu Jezusa do Jerozolimy, w tym także podwójną liczbę osłów, na tle typologii Mojżesz - Jezus ${ }^{118}$.

Przytaczane są następujące argumenty za udowodnieniem powyższej tezy.


z rodzajnikiem, w miejsce ogólnego rzeczownika bez rodzajnika. Taki zapis może wskazywać na konkretnego proroka, w tym oczekiwanego proroka na kształt Mojżesza. (2) Jezus przedstawiony jest w Mateuszowej narracji o triumfalnym wjeździe do Jerozolimy jako król i prorok jednocześnie, co odpowiada charakteryzacji Mojżesza w pismach Filona oraz w źródłach rabinackich i sa-

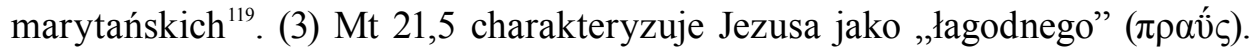
Przymiotnik ten, charakteryzujący postać Mojżesza jako najbardziej pokornego z wszystkich ludzi (Lb 12,3), występuje także w Mt 5,5 oraz 11,29, gdzie można dostrzec nawiązania do Mojżesza. W ten sposób opis Jezusa jako osoby łagodnej jest przygotowany przez wcześniejsze Mateuszowe nawiązania do Mojżesza (5,5; 11,29) i wskazuje na Mojżeszową typologię mesjańską. (4) Obecność wołających dzieci w Mt 21,15 może być wyjaśniona aluzją do Ps 8,3 („Przygotowałeś sobie uwielbienia nawet z ust niemowląt i jeszcze ssących”, tłum. R. Popowski), który w tradycji rabinackiej łączony jest ze śpiewem dzieci w czasie exodusu, a dokładnie z pieśnią z Wj $15^{120}$. Połączenie między śpiewem dzieci i przejściem przez Morze Czerwone odzwierciedlone jest także w Mdr 10,21 („,Mądrość [...] wymownym uczyniła język małych dzieci”, tłum. R. Popowski). W życiu Mojżesza i Jezusa pojawia się zatem epizod śpiewu dzieci. (5) W Mt 21,15 arcykapłani

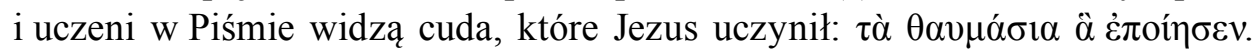
Praktycznie to samo wyrażenie kończy Pięcioksiąg, odnosząc się do cudów

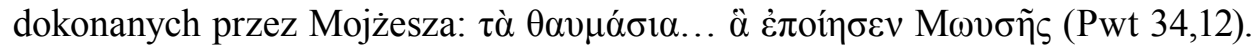
(6) Obraz Mojżesza jadącego na ośle obecny jest w literaturze rabinackiej (Rodzaju Rabba 32,6; Pirke R. El. 31). Przyszły Mesjasz ma objawić się na końcu czasów na tym samym ośle, na którym Mojżesz zmierzał do Egiptu w celu wyzwolenia swego ludu. Wcześniej Abraham jechał na nim na Górę Moria (Pirke R. El. 31) ${ }^{121}$. Co więcej, powiązanie między Mojżeszem a osłem znajdujemy nawet

117 Zob. Allison, The New Moses.

118 Allison, New Moses, 250-253; Davies - Allison, Matthew, III, 121.

119 W.A. Meeks, The Prophet-King. Moses Traditions and the Johannine Christology (NT.S 14; Leiden: Brill 1967) passim.

120 t. Sota 6,4; Mekilla do Wj 15,1; por. b. Ber. 56b; b. Sota 30b; Tg Yer. Wj 15,2; Midrasz do Ps 8,5.

121 L. Ginzberg, Legends of the Jews. I. Bible Times and Characters from the Creation to Moses in the Wilderness (JPS Classic Reissues; Philadelphia, PA: The Jewish Publication Society ${ }^{2} 2003$ ) 515. W świetle Pirque R. El. 18, dokumentu datowanego na IX w. po Chr., pośród pierwszych dziesięciu rzeczy stworzonych w wigilię pierwszego szabatu stworzenia był także osioł. Był 
w literaturze pogańskiej. Diodor Sycylijski, historyk grecki z I w. przed Chr., twierdził (Bibliotheca historica 34,1), że Antioch, walcząc z Żydami, wkroczył do Świątyni Jerozolimskiej, gdzie znalazł kamienne wyobrażenie brodatego człowieka jadącego na ośle i trzymającego w ręku księgę. Postać ta została przezeń zidentyfikowana jako Mojżesz, założyciel Jerozolimy. Na przełomie I i II w. po Chr. Tacyt (Hist. 5,3) stwierdził, że Mojżesz znalazł wodę na pustyni, podążając za stadem dzikich osłów. Starożytni poganie (a przynajmniej jakaś ich część) mieli również wierzyć, iż Żydzi czczą osła. Źródłem tego poglądu miał być pogański filozof Posejsdonios z Apamei (II/I w. przed Chr.) ${ }^{122}$. (7) Tradycja rabinacka (Kohelet Rabba 1,28; zob. Samuel Rabba 14,9 [45b]; Pirke R. El. 31) łączy proroctwo Za 9,9 (cytowane przez Mateusza) z Wj 4,20. Tekst masorecki Wj 4,20 mówi, iż Mojżesz wziął swą żonę i swych synów i posadził ich na ośle,

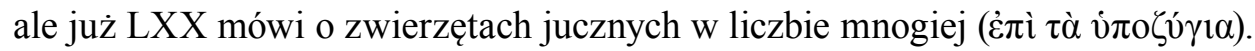
Mateuszowy akcent położony na obecności dwojga zwierząt, wraz z cytatem Za 9,9, może być zatem wskazaniem, iż Zachariaszowe proroctwo wypełnia się w Jezusie ukazanym jako Mojżeszowy Mesjasz.

Dalle C. Allison wymienia dwa argumenty na poparcie tezy o związku Wj 4,20 z Mt 21,1-11. Po pierwsze, aluzja do Wj 4,20 występuje w Mateuszowej Ewangelii dzieciństwa Jezusa $(2,19-21)$, gdzie wyraźnie wskazuje na typologię Mojżesz - Jezus. Po drugie, użycie Wj 4,20 w Mateuszowej Ewangelii dzieciństwa, wraz z zastosowaniem się do dwóch ówczesnych zasad hermeneutycznych - (1) ostatnie rzeczy są takie jak pierwsze (Kohelet Rabba 1,28) oraz (2) dwa

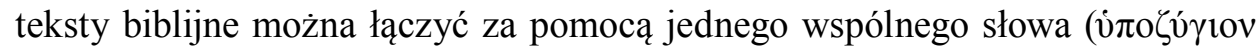
występuje w Wj 4,20; Za 9,9 oraz Mt 21,5) - doprowadziło do wzajemnego interpretowania $\mathrm{Wj}$ 4,20 i Za 9,9, jednego tekstu w świetle drugiego, i uzyskaniem przez Mateusza obrazu dwóch osłów. Nadto, lektura dwóch osłów w tekście Za 9,9 jest ułatwiona przez specyficzną składnię LXX.

Wszystkie powyższe argumenty stanowią dla D.C. Allisona podstawę do twierdzenia, że temat nowego Mojżesza jest istotnym motywem obecnym w Mateuszowym opisie triumfalnego wjazdu Jezusa do Jerozolimy ${ }^{123}$. Nie bez znaczenia jest także fakt, iż lektura Mateuszowego opisu triumfalnego wjazdu Jezusa do Jerozolimy w kluczu typologii Mojżeszowej obecna jest już w starożytności w pismach św. Hieronima: „Posyła swych uczniów, aby tak jak jedzie

on użyty przez Abrahama (Rdz 22,3), a następnie przez Mojżesza (Wj 4,20). W przyszłości ma on być użyty przez Mesjasza.

122 Więcej na temat powiązania między Mojżeszem i osłem w P. Borgeaud, „Moïse, son âne et les Typhoniens: esquisse pour une remise en perspective", La construction de la figure de Moïse. The Construction of the Figure of Moses (red. T. Römer) (Supplément n ${ }^{\circ} 13$ à Transeuphratène; Paris: Gabalda 2007) 121-130.

123 Allison, New Moses, 250-253. 
na źrebięciu oślicy, mógł jechać na tobie, wyzwalając cię z trosk tego świata, tak byś mógł opuścić cegły i słomę Egiptu i mógł iść za Nim, prawdziwym Mojżeszem, przez pustynię i wejść do ziemi obietnicy" (Ep. 22,24) $)^{124}$.

Typologia Dawidowo-Salomonowa. Maarten J.J. Menken zauważa, iż w Mateuszowej narracji o triumfalnym wjeździe do Jerozolimy zawarta jest

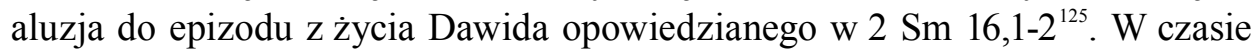
ucieczki Dawida przed Absalomem niejaki Siba przybywa na pomoc z parą

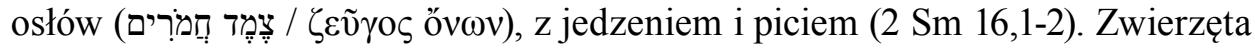
te mają również posłużyć rodzinie królewskiej, która ma na nich usiąść ( $\tau \alpha$

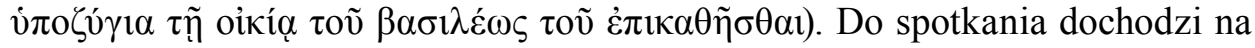
Górze Oliwnej, a dokładnie w miejscu, w którym Dawid przekroczył już szczyt góry $\mathrm{i}$ jest na jej wschodnim stoku. Dokładnie w tym miejscu znajdowała się w czasach Jezusa wioska Betfage, z której dwóch uczniów przyprowadziło do Jezusa parę osłów.

Jak zauważa Menken, pomimo ewidentnych różnic (Dawid uchodzi z miasta, a Jezus doń przybywa), paralela między tekstem Mateusza i opowiadaniem o Dawidzie jest oczywista: (1) to samo miejsce (Góra Oliwna); (2) przyprowadzenie dwóch osłów; (3) określenie zwierząt jako juczne przez użycie terminu

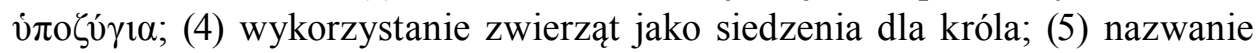
Jezusa przez thum „Synem Dawida” (21,9.15).

Do powyższych paraleli podanych przez Menkena można dodać użycie tytułu „król” ( $\beta \alpha \sigma i \lambda \varepsilon v ́ \varsigma)$ zarówno w odniesieniu do Dawida (2 Sm 16,2), jak i Jezusa $(21,5)$ oraz użycie pokrewnych czasowników na określenie czynności siedzenia

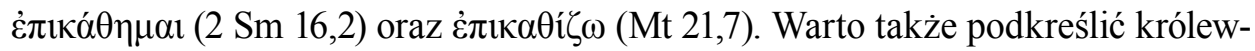
ski charakter perykopy Mt 21,1-11, gdyż jest to pierwsze w narracji Mateusza publiczne wskazanie na królewską godność Jezusa (choć nie bezpośrednio przez słowa, ale pośrednio przez czyny) oraz pierwsze publiczne uznanie królewskiej godności Jezusa (czynią to tłumy) ${ }^{126}$. Nadto zaraz po wjeździe do Jerozolimy Jezus

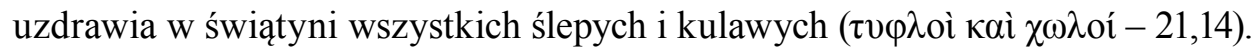
Jest to aluzja do narracji z 2 Sm 5,6.8, w której zdobywającego Jerozolimę Dawida

124 Mittit discipulos suos, ut in pullo asinae curis te saecularibus solvant, ut paleas et lateres Aegypti derelinquens Moysen sequaris in heremo et terram repromissionis introeas (LCL 262,106).

125 M.J.J. Menken, „The Quotations from Zech 9,9 in Mt 21,5 and in Jn 12,15”, John and the Synoptics (red. A. Denaux) (BEThL 101; Leuven: Leuven University Press - Peeters 1992) 574-575; Meneken, „Context”, 111. Hipoteza poparta również przez J. Nieviarts, L'entrée de Jésus à Jérusalem (Mt 21,1-17). Messianisme et accomplissement des Écritures en Matthieu (Lectio Divina 176; Paris: Cerf 1999) 55; Mitch - Sri, Matthew, 265.

126 Davies - Allison, Matthew, III, 112. 


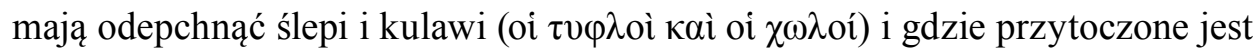
powiedzenie: „Ślepy i kulawy nie wejdzie do świątyni”.

Podsumowując, zdaniem M.J.J. Menkena wpływ 2 Sm 16,1-4 wyjaśnia Mateuszową relekturę Za 9,9 jako tekstu mówiącego o dwóch osłach, w miejsce jednego. Zdaniem W. Werena słabym punktem tej hipotezy jest brak wyraźne-

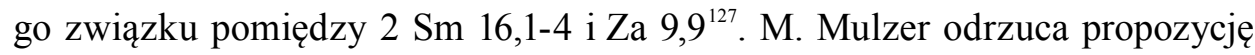
M.J.J. Menkena, gdyż narracja w $2 \mathrm{Sm} 16$ nie wspomina wprost o fakcie dosiadania przez króla osła czy osłów. Narracja ta nie mówi także, iż zwierzęta te są przeznaczone jedynie dla króla. Nie ma także wyraźnego podziału na dwa osły. Samo zaś wydarzenie nie ma charakteru eschatologicznego znaku, jaki ma w narracji Mateusza ${ }^{128}$.

Kilku komentatorów chce widzieć w Mt 21,1-11 nawiązanie do Salomona wjeżdżającego do Jerozolimy na Dawidowej mulicy (1 Krl 1,28-40) ${ }^{129}$. Można przedstawić kilka argumentów za powyższą tezą. (1) Narracje ewangeliczne, w tym Mateuszowa, akcentują użycie przez Jezusa osiołka jako zwierzęcia wierzchowego. Podobna emfaza na środku transportu, w kontekście wjazdu królewskiego do Jerozolimy, występuje jedynie w $1 \mathrm{Krl}$ 1,28-40 oraz Za 9,9 $9^{130}$. (2) Należy podkreślić, iż cytat z Za 9,9 przywołuje obraz Dawidowego króla, który zniszczy wszelką broń, obwieści ludom pokój i którego panowanie będzie się rozciągać na krańce ziemi (Za 9,10). Taki obraz odpowiada jedynie Salomonowi, królowi pokoju, którego rządy charakteryzował pokój, a granice jego królestwa sięgały najdalej w historii Izraela (zob. Salomonowy Ps 72,7-8). (3) Według Mateusza okrzyk wiwatującego tłumu brzmiał „Hosanna Synowi Dawida!” $(21,9)$, a zatem przywoływano postać Salomona, syna Dawida, jako typu przyszłego Mesjasza. Warto zauważyć, iż okrzyk tłumu w relacji Marka dotyczy samego Dawida: „Błogosławione królestwo ojca naszego, Dawida” (11,10). (4) Zdaniem Bena Witheringtona istotnym argumentem za dostrzeżeniem w Mt 21,1-11 ty-

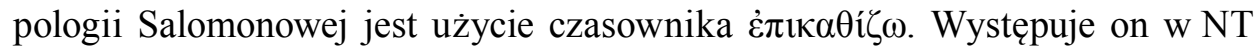
jedynie w Mt 21,7, natomiast pośród ośmiu wystąpień w LXX aż dwa określają Salomona siedzącego na mulicy w czasie jazdy do źródła Gihon oraz swego intronizacyjnego wjazdu do Jerozolimy $(1 \mathrm{Krl} 1,38.44)^{131}$. (5) Poruszenie całego miasta $(\pi o ́ \lambda ı \varsigma)$ na wieść o wjeździe Jezusa (Mt 21,10) przypomina zachowanie

127 Weren, „Jesus' Entry into Jerusalem”, 132.

128 Mulzer, „Ein Esel, zwei Esel?”, 86: „Weder wird allerdings das Reiten des Königs bestimmt und somit ein Charakteristikum, geschweige denn ein eschatologisches Erkennungszeichen für diesen zu sein; auch werden die beiden Esel im Gespann nicht explizit voneinander unterschieden".

129 Nieviarts, L'entrée, 250; B. Witherington, Matthew (Smith \& Helwys Bible Commentary; Macon, GA: Smith \& Helwys 2006) 388-389; G.R. Osborne, Matthew (ZECNT; Grand Rapids, MI: Zondervan 2010) 755.

130 Por. Davies - Allison, Matthew, III, 113.

131 Witherington, Matthew, 389. 
mieszkańców miasta ( $\pi$ ódı) Jerozolimy w czasie wjazdu Solomona po namaszczeniu przy źródle Gichon (1 Krl 1,41.45). (6) Zdaniem C.H. Spurgeona użycie przez Jezusa ubogiego środka transportu, jakim był osiołek, tworzy kontrast z Salomonem, który sprowadzał konie dla podkreślenia swej pozycji i bogactwa (1 Krl 10,26-29; 2 Krn 1,14; 9,25) ${ }^{132}$. W istocie obecność konia w biblijnej historii Izraela, nie licząc egipskiego epizodu Józefa ( $R d z$ 46,29; 47,17; 50,9), rozpoczyna się z postaciami Absaloma (2 Sm 15,1) oraz Salomona (1 Krl 10,26-29) ${ }^{133}$. Warto jednak zauważyć, iż w czasie wjazdu do miasta Salomon używa mulicy (hybrydy konia i osła) swego ojca. Akcent spoczywa zatem nie tyle na kategorii ubóstwo/bogactwo w odniesieniu do środka transportu, ile na królewskości wierzchowca. W tym sensie także Jezusowa oślica, poprzez nawiązanie do Za 9,9, jest wierzchowcem królewskim ${ }^{134}$. (7) Mateusz pomija w cytacie z Za 9,9 przymiotniki „sprawiedliwy” oraz „zwycięski”, które mogą harmonizować z typologią Salomonową (sprawiedliwość) oraz Dawidową (zwycięstwo). Pozostawienie jedynie przymiotnika „pokorny” przywołuje Mojżesza, z drugiej jednak strony może się łączyć z zapowiedzią usunięcia wszelkiej broni w Za 9,10, a zatem z ideą pokoju, cechą Salomona.

\section{Podsumowanie i wnioski}

Celem artykułu była krytyczna prezentacja motywów, dla których Mateusz kładzie tak duży nacisk na obecność dwóch osłów w opisie triumfalnego wjazdu Jezusa do Jerozolimy. W efekcie w artykule znalazł się opis, systematyzacja i w dużej części krytyczna ocena całej gamy opinii dotyczących tego problemu, dając swoiste status quaestionis.

Przedstawiono motywy zakorzenione w interpretacjach alegorycznych, naturalistycznych, odwołujących się do pracy redakcyjnej oraz intertekstualności,

132 Spurgeon, The Gospel of the Kingdom, 342.

133 D. O'Daniel Cantrell, The Horsemen of Israel. Horses and Chariotry in Monarchic Israel (Ninth-Eight Centuries B.C.E.) (HACL 1; Winona Lake, IN: Eisenbrauns 2011).

134 O ośle jako wierzchowcu królewskim zob. $1 \mathrm{Sm}$ 25,20.2342; $2 \mathrm{Sm}$ 16,1-2; 19,26 [MT 19,27]; Za 9,9; por. Rdz 49,10-11; Sdz 5,10; 1 Sm 9-10. W przypadku Za 9,9-10 osioł, symbolizujący pokój, porównany jest $\mathrm{z}$ koniem symbolizującym wojnę. Oboje zwierząt $\mathrm{w}$ tym tekście funkcjonuje jako symbole królewskie. Zwrócono uwagę, iż w akadyjskim tekście z Mari $(A R M 6,76)$ występuje podobne symboliczne porównanie pomiędzy koniem i mułem. W świetle tego datowanego na średni brąz (XVIII w.) tekstu król winien dosiadać muła (czy też użyć rydwanu ciągniętego przez muły), ale nie konia, którego dopiero co zaczęto udamawiać. Way, Donkeys, 82-86 oraz 172. Warto także wspomnieć o sumeryjskim hymnie króla Shulgi, w którym król nazywa siebie „dumnym osłem”. Zachariaszowe połączenie pokornego króla i osła zyskuje zatem na wyrazistości. Więcej o królewskiej symbolice osła zob. G. Hanfman, „The Donkey and the King", HTR 78 (1985) 421-426. 
w tym typologii. Jako że jednym z głównych celów spisania Ewangelii była chęć dokładnego opisania wydarzeń z życia Jezusa, niezwykle przekonująca jest jedna $z$ interpretacji naturalistycznych, w świetle której przyprowadzono do Jezusa dwoje zwierząt (oślicę i źrebię) i mimo że Jezus dosiadał tylko jedno $\mathrm{z}$ nich, drugie cały czas towarzyszyło pierwszemu. Racją wspominania o dwojgu zwierzętach była zatem chęć dokładnego, wręcz drobiazgowego opisania rzeczywistości. Wyrażenie siedział „na nich” można zatem zrozumieć jako odwołanie do naturalnej jedności czy też nierozłączności matki samicy z młodym źrebakiem.

Biorąc pod uwagę teologiczny charakter dzieła Mateusza, należy także uznać, iż opisywane fakty zostały zinterpretowane teologicznie. Niezwykła wrażliwość Mateusza na ukazywaniu związków pomiędzy wydarzeniami z życia Jezusa oraz tekstami ST wskazuje na intertekstualność jako na najbardziej obiecujące źródło teologicznych motywacji ewangelisty. Związki z tekstami ST mogą zatem, w naszej opinii, najlepiej wyjaśnić problematyczną kwestię poruszaną w artykule. Spośród różnych starotestamentalnych odniesień najbardziej przekonuje odwołanie do Za 9,9, tekstu wprost cytowanego przez ewangelistę, oraz dwóch typologii: Mojżeszowej i Dawidowo-Salomonowej. Odnośnie do użycia przez Mateusza Za 9,9, w naszej opinii najbardziej wiarygodne są trzy rozwiązania:

(1) Jeśli przyjmiemy, że Mt 21,7 mówi o siedzeniu Jezusa na dwojgu zwierzętach, wówczas wydaje się logicznym, iż Mateusz rozumiał cytat z Za 9,9 jako mówiący o dwojgu zwierzętach. W tym przypadku Mateusz czytał wyrocznię w Za 9,9 poprzez pryzmat paralelizmu syntaktycznego. Na prawdopodobieństwo takiej lektury wskazuje chociażby starożytne tłumaczenie Teodocjona, wykazującego w Za 9,9 dwa osły różnej płci w kolejności Mateuszowej: oślica i źrebię. Warto podkreślić, iż recenzja Teodocjona i Ewangelia Mateusza powstają w tym samym czasie. Oba teksty są zatem świadkami egzegezy Za 9,9, w której widziano dwa osły: oślicę i źrebię. Według naszej wiedzy nikt z dotychczasowych komentatorów Mt 21,1-11 nie zwrócił uwagi na tłumaczenie Teodocjona jako argumentu za możliwością interpretacji opisu zwierząt w Za 9,9 jako paralelizmu syntaktycznego. Interpretacja ta byłaby także potwierdzona przez tezę Davida Instone-Brewera, iż w I w. po Chr. w pewnych kręgach rabinackich interpretowano paralelizm jak tekst prawny, a zatem nadający obu członom paralelizmu odrębne znaczenie.

(2) Możliwym jest również rozumienie stwierdzenia z Mt 21,7 o „siedzeniu na nich", jako mówiącym o siedzeniu na jednym zwierzęciu, czy to poprzez rozumienie oślicy i źrebięcia jako nierozdzielnej całości (zob. wyjaśnienia naturalistyczne), czy przez odwołanie do figur retorycznych (np. synekdocha, enallage numeri, syllepsa). Wzmiankowanie w narracji dwojga zwierząt $(21,2.3 .5 .7)$ także winno być rozumiane jako mówienie o jednym zespole zwierząt, a więc 
pojedynczej rzeczywistości. Wówczas cytat z Za 9,9 rozumiany jest poprzez pryzmat paralelizmu synonimicznego jako mówiący o jednym zwierzęciu.

(3) Mateusz, poprzez literalne przytoczenie w języku greckim formy hebrajskiej Za 9,9, wskazał także na możliwość dostrzeżenia w tekście wyroczni dwóch osłów bez konieczności negowania zasady paralelizmu synonimicznego (hipoteza R.H. Gundry'ego). Jezus wjechał w rzeczywistości na jednym ośle płci męskiej (któremu towarzyszyła oślica), a cytat z Za 9,9 wskazujący na jednego osła płci męskiej zawiera w swym drugim członie również informację o obecności oślicy. Forma tekstualna Za 9,9 mogła zatem doskonale odpowiadać historycznej rzeczywistości.

Szukając teologicznych motywacji użycia Za 9,9, nie można mieć wątpliwości, iż Mateusz poprzez cytat chciał pokazać związek między tym proroctwem i wydarzeniem wjazdu Jezusa do Jerozolimy. Wskazuje na to treść formuły wprowadzającej cytat (jaką jest wypełnienie) oraz centralne miejsce cytatu w perykopie. Cytowane proroctwo w swej wymowie jest mesjańskie i wskazuje na Jezusa jako obiecanego Mesjasza. Nadto, poprzez obecne w narracji aluzje do typologii Mojżeszowej i Dawidowo-Salomonowej, Mateusz maluje portret Jezusa jako pokornego proroka na wzór Mojżesza oraz przynoszącego pokój króla Mesjasza, Salomona, syna Dawida.

\section{Bibliografia}

Allison, D.C., The New Moses. A Matthean Typology (Minneapolis, MN: Augsburg Fortress 1993). Alter, R., The Art of Biblical Poetry (New York: Basic Books 1985).

Baraniak, M., Prorok jak Mojżesz (Pwt 18,9-22). Hermeneutyka prawa o urzędzie proroka w Izraelu (Rozprawy i Studia Biblijne 19; Warszawa: Vocatio 2005).

Barthélemy, D., Les devanciers d'Aquila. Première publication intégrale du texte des fragments du Dodécaprophéton trouvés dans le désert de Juda, précédée d'une étude sur les traductions et recensions grecques de la Bible réalisées au premier siècle de notre ère sous l'influence du rabbinat palestinien (Supplements to Vetus Testamentum 10; Leiden: Brill 1963).

Bartnicki, R., „Das Zitat von Zach IX, 9-10 und die Tiere im Bericht von Matthäus über dem Einzug Jesu in Jerusalem (Mt XXI, 1-11)", Novum Testamentum 18 (1976) 161-166.

Bartnicki, R., „Tekst Za 9,9-10 w perykopach Mt 21,1-11 i J 12,12-19”, Studia Theologica Varsaviensia 14/2 (1976) 47-65.

Bauer, D.R., Treasures New and Old. Recent Contributions to Matthean Studies (SBL Symposium Series 1; Atlanta: Scholars 1996).

Bauer, W., „The Colt of Palm Sunday (Der Palmesel)”, Journal of Biblical Literature 72 (1953) 220-229.

Blass, F. - Debrunner, A., A Greek Grammar of the New Testament and Other Early Christian Literature (tłum. R. Funk) (Chicago, IL - London: The University of Chicago Press 1961) $(=\mathrm{BDF})$. 
Blenkinsopp, J., „The Oracle of Judah and the Messianic Entry”, Journal of Biblical Literature 80 (1961) 55-64.

Borgeaud, P., „Moïse, son âne et les Typhoniens: esquisse pour une remise en perspective”, $L a$ construction de la figure de Moïse. The Construction of the Figure of Moses (red. T. Römer) (Supplément $n^{\circ} 13$ à Transeuphratène; Paris: Gabalda 2007) 121-130.

Caesarius of Arles, Saint Caesarius of Arles. Sermons. II. Sermons 81-186 (The Fathers of the Church 47; Washington, DC: The Catholic University of America Press 1964).

Coppins, W., „Sitting on Two Asses? Second Thoughts on the Two-Animal Interpretation of Matthew 21:7", Tyndale Bulletin 63/2 (2012) 275-290.

Davies, W.D. - Allison, D.C., A Critical and Exegetical Commentary on the Gospel according to Saint Matthew. III. Commentary on Matthew XIX-XXVIII (International Critical Commentary; Edinburgh: T\&T Clark 1997).

Derrett, J.D.M., „Law in the New Testament: The Palm Sunday Colt”, Novum Testamentum 13 (1971) 241-258.

Dupont, J., „L'entrée messianique de Jésus à Jérusalem (Mt 21,1-17)”, Assemblées du Seigneur 37 (1965) 46-32.

Evans, C.A., „Jesus and Zechariah's Messianic Hope”, Authenticating the Activities of Jesus (red. B.D. Chilton - C.A. Evans) (New Testament Tools and Studies 28/2; Leiden - Boston, MA - Köln: Brill 1999) 373-388.

Evans, C.A., Matthew (New Cambridge Bible Commentary; Cambridge: Cambridge University Press 2012).

Fillion, L.C., The Life of Christ. A Historical, Critical, and Apologetic Exposition (St. Louis, MO - London: Herder 1938-1941) I-III.

Fortunatianus Aquileiensis, Commentary on the Gospels. English Translation and Introduction (Corpus Scriptorum Ecclesiasticorum Latinorum; Berlin - Boston, MA: De Gruyter 2017).

Fowler, H., The Gospel of Matthew (Bible Study Textbooks Series; Joplin, MO: College Press 1985) I-IV.

France, R.T., Matthew. An Introduction and Commentary (Downers Grove, IL: InterVarsity 1985).

France, R.T., The Gospel of Matthew (The New International Commentary on the New Testament; Grand Rapids, MI - Cambridge, U.K.: Eerdmans 2007).

Frenz, A., „Mt XXI 5.7”, Novum Testamentum 13 (1971) 259-260.

Gesenius, W., Gesenius's Hebrew and Chaldee Lexicon to the Old Testament Scriptures (Grand Rapids, MI: Eerdmans 1950).

Ginzberg, L., Legends of the Jews. I. Bible Times and Characters from the Creation to Moses in the Wilderness (JPS Classic Reissues; Philadelphia, PA: The Jewish Publication Society ${ }^{2} 2003$ ).

Gnilka, J., Das Matthäusevangelium. II. Kommentar zu Kap. 14,1-28,20 und Einleitungsfragen (Herders Theologischer Kommentar zum Neuen Testament; Freiburg - Basel - Wien: Herder $\left.{ }^{2} 1992\right)$.

Gray, G.B., The Forms of Hebrew Poetry. Considered with Special Reference to the Criticism and Interpretation of the Old Testament (The Library of Biblical Studies; New York: Ktav 1972).

Grundmann, W., Das Evangelium nach Matthäus (Theologischer Handkommentar zum Neuen Testament; Berlin: Evangelische Verlagsanstalt ${ }^{2}$ 1971).

Gundry, R.H., Commentary on the New Testament. Verse-by-Verse Explanation with a Literal Translation (Peabody, MA: Hendrickson Publishers 2010).

Gundry, R.H., Matthew. A Commentary on His Literary and Theological Art (Grand Rapids, MI: Eerdmans 1982). 
Gundry, R.H., The Use of the Old Testament in St. Matthew's Gospel with Special Reference to the Messianic Hope (Supplements to Novum Testamentum 18; Leiden: Brill 1967).

Haenchen, E., Der Weg Jesu. Eine Erklärung des Markus-Evangeliums und der kanonischen Parallelen (Sammlung Töpelmann II,6; Berlin: Töpelmann 1966).

Hagner, D.A., Matthew 14-28 (Word Biblical Commentary 33B; Dallas, TX: Word 1998).

Hanfman, G., „The Donkey and the King”, Harvard Theological Review 78 (1985) 421-426.

Hare, D.R.A., Matthew (Interpretation. A Bible Commentary for Teaching and Preaching; Louisville, KY: John Knox Press 1993).

Harl, M. - Dogniez, C. - Brottier, L. - Casevitz, M. - Sandevoir, P. (red.), La Bible d'Alexandrie. XXIII. Les douze prophètes. 4-9. Joël, Abdiou, Jonas, Naoum, Ambakoum, Sophonie (Paris: Cerf 1999).

Harrington, D.J., The Gospel of Matthew (Sacra Pagina 1; Collegeville, MN: The Liturgical Press 1991).

Haydock, G.L., Haydock's Catholic Bible Commentary (New York: Edward Dunigan and Brother 1859).

Holtzmann, O., Das Neue Testament nach dem Stuttgarter griechischen Text. I. Die synoptischen Evangelien. Apostelgeschichte (Giessen: Töpelmann 1926).

Instone-Brewer, D., „The Two Asses of Zechariah 9:9 in Matthew 21”, Tyndale Bulletin 54/1 (2003) 87-98.

Instone-Brewer, D., Techniques and Assumptions in Jewish Exegesis before 70 CE (Texte und Studien zum Antiken Judentum 30; Tübingen: Mohr Siebeck 1992).

Keener, C.S., The Gospel of Matthew. A Socio-Rhetorical Commentary (Grand Rapids, MI Cambridge, U.K.: Eerdmans 2009).

Keil, C.F. - Delitzsch F., Commentary on the Old Testament. X. The Minor Prophets (Peabody, MA: Hendrickson 2006).

Krause, D., „The One who Comes Unbinding the Blessing of Judah: Mark 11.1-10 as a Midrash on Genesis 49.11, Zechariah 9.9, and Psalm 118.25-26", Early Christian Interpretation of the Scriptures of Israel. Investigations and Proposals (red. C.A. Evans - J.A. Sanders) (JSNT.S 148; Sheffield: Sheffield Academic Press 1997) 141-153.

Kubiś, A., The Book of Zechariah in the Gospel of John (Études Biblique. Nouvelle Série 64; Pendé: Gabalda et $C^{\text {ie }}$ 2012).

Kubiś, A., „Drzewo figowe, osioł i woda żywa. Rola Księgi Zachariasza w Ewangelii Janowej”, Resovia Sacra 22 (2015) 211-237.

Kubiś, A., „Dlaczego w relacji Mateusza (21,1-11) Jezus wjeżdżał do Jerozolimy na dwóch osłach?

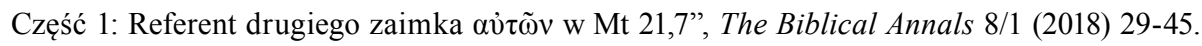

Kuhn, H.W., „Das Reittier Jesu in der Einzugsgeschichte des Markusevangeliums”, Zeitschrift für die neutestamentliche Wissenschaft und die Kunde der älteren Kirche 50 (1959) 82-91.

Lagrange, J.-M., Évangile selon Saint Matthieu (Études Biblique; Paris: Gabalda et C C $^{\mathrm{ie}} 1923 .{ }^{3} 1927$ ).

Lapide, C. à, Commentaria in Scripturam Sacram [...] editio nova [...]. XV. In SS. Matthaeum et Marcum (Parisiis: Vivès 1867).

Lapide, P., Bibbia tradotta Bibbia tradita (Studi Biblici 36; Bologna: EDB 2000).

Lindars, B., New Testament Apologetic. The Doctrinal Significance of the Old Testament Quotations (London: SCM 1961).

Lipiński, E., „Recherches sur le livre de Zacharie”, Vetus Testamentum 20 (1970) 25-55.

Loisy, A., Les Évangiles synoptiques (Ceffonds près Montier-en-Der [Haute-Marne]: chez l'auteur 1907-1908) I-II. 
Luz, U., Matthew 21-28. A Commentary (Hermeneia - A Critical and Historical Commentary on the Bible; Minneapolis, MN: Fortress 2005).

Maas, A.J., The Gospel according to Saint Matthew with an Explanatory and Critical Commentary (St. Louis, MO: B. Herder 1898).

MacEvilly, J., An Exposition of the Gospels of Matthew and Mark (Dublin - New York: M.H. Gill \& Son - Benziger Brothers 1898).

Maldonatus, J., A Commentary on the Holy Gospels (London: John Hodges 1888).

McCasland, S.V., „Matthew Twists the Scriptures”, Journal of Biblical Literature 80 (1961) 143-148.

Meeks, W.A., The Prophet-King. Moses Traditions and the Johannine Christology (Supplements to Novum Testamentum 14; Leiden: Brill 1967).

Meier, J.P., The Vision of Matthew. Christ, Church, and Morality in the First Gospel (Eugene, OR: Wipf and Stock 2004; pierwsze wyd. New York, NY: Paulist 1979).

Menken, M.J.J., „The Quotations from Zech 9,9 in Mt 21,5 and in Jn 12,15”, John and the Synoptics (red. A. Denaux) (Bibliotheca Ephemeridum Theologicarum Lovaniensium 101; Leuven: Leuven University Press / Peeters 1992) 571-578.

Menken, M.J.J., „Context and Textual Form of the Quotation from Zechariah 9,9 in Matthew 21,5", Matthew's Bible. The Old Testament Text of the Evangelist (Bibliotheca Ephemeridum Theologicarum Lovaniensium 173; Leuven: Leuven University Press/Peeters 2004) 104-116.

Meyer, B.F., „Appointed Deed, Appointed Doer: Jesus and the Scriptures”, Authenticating the Activities of Jesus (red. B.D. Chilton - C.A. Evans) (New Testament Tools and Studies 28/2; Leiden - Boston, MA - Köln: Brill 1999) 155-176.

Meyers, C.L. -Meyers, E.M., Zechariah 9-14 (The Anchor Bible 25C; New York, NY: Doubleday 1993).

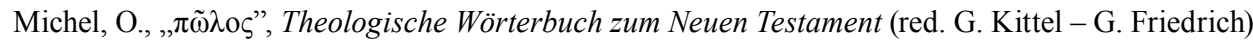
(Stuttgart: Kohlhammer 1959) VI, 959-961.

Mitch, C. - Sri, E., The Gospel of Matthew (Catholic Commentary on Sacred Scripture; Grand Rapids, MI: Baker Academic 2010).

Mounce, R.H., Matthew (New International Biblical Commentary. New Testament Series 1; Peabody, MA: Hendrickson 1991).

Mulzer, M., „Ein Esel, zwei Esel? Zu Sach 9,9 und Mt 21,2.5.7”, Biblische Zeitschrift 59 (2015) 79-88.

Nepper-Christensen, P., Das Matthäusevangelium - ein judenchristliches Evangelium? (Acta Theologica Danica 1; Aarhus: Universitets-Forlaget 1958).

Nieviarts, J., L'entrée de Jésus à Jérusalem (Mt21,1-17). Messianisme et accomplissement des Écritures en Matthieu (Lectio Divina 176; Paris: Cerf 1999).

Nolland, J., The Gospel of Matthew. A Commentary on the Greek Text (The New International Greek Testament Commentary; Grand Rapids, MI - Cambridge, U.K.: Eerdmans 2005).

O'Daniel Cantrell, D., The Horsemen of Israel. Horses and Chariotry in Monarchic Israel (NinthEight Centuries B.C.E.) (History, Archaeology, and Culture of the Levant 1; Winona Lake, IN: Eisenbrauns 2011).

Orygenes, Komentarz do Ewangelii wedtug św. Jana (tłum. S. Kalinkowski) (Źródła Myśli Teologicznej 27; Kraków: WAM 2005).

Osborne, G.R., Matthew (Zondervan Exegetical Commentary on the New Testament; Grand Rapids, MI: Zondervan 2010).

Paciorek, A., Ewangelia według świętego Mateusza. Rozdziały 14-28 (Nowy Komentarz Biblijny. Nowy Testament I/2; Częstochowa: Edycja Świętego Pawła 2005). 
Pesch, R., „Eine alttestamentliche Ausführungsformel im Matthäus-Evangelium: Redaktionsgeschichtliche und exegetische Beobachtungen", Biblische Zeitschrift 10 (1966) 220-245.

Pieper, K., „Zum Einzug Jesu in Jerusalem”, Biblische Zeitschrift 11 (1913) 397-402.

Reuss, J., Matthäus-Kommentare aus der griechischen Kirche (Texte und Untersuchungen zur Geschichte der altchristlichen Literatur 61/V.6; Berlin: Akademie Verlag 1957).

Rölver, O., Christliche Existenz zwischen den Gerichten Gottes. Untersuchungen zur Eschatologie des Matthäusevangeliums (Bonner Biblische Beiträge 163; Göttingen: V\&R unipress / Bonn University Press 2010).

Schuchard, B.G., Scripture within Scripture. The Interrelationship of Form and Function in the Explicit Old Testament Citations in the Gospel of John (SBL Dissertation Series 133; Atlanta, GA: Scholars Press 1992).

Senior, D. (red.), The Catholic Study Bible (New York - Oxford: Oxford University Press 1990).

Smith, R.H., Matthew (Augsburg Commentary on the New Testament; Minneapolis, MN: Augsburg Publishing House 1989).

Smith, R.L., Micah-Malachi (WBC 32; Waco, TX: Word Book 1984).

Speiser, E.A., Genesis. Introduction, Translation, and Notes (The Anchor Bible 1; New York, NY: Doubleday 1964).

Spurgeon, C.H., The Gospel of the Kingdom. A Popular Exposition of the Gospel according to Matthew (New York, NY: Baker \& Taylor 1893).

Stanley, D.M., „Études matthéennes: L'entrée messianique à Jérusalem”, Science et Esprit 6 (1954) 93-106.

Stavsky, Y., Trei asar. The Twelve Prophets. A New Translation with a Commentary Anthologized from Talmudic, Midrashic, and Rabbinic Sources. II. Micah, Nahum, Habakkuk, Zephania, Haggai, Zechariah, Malachi (The ArtScroll Tanach Series; Brooklyn, NY: Mesorah 2009).

Stendahl, K., The School of St. Matthew and Its Use of the Old Testament (Acta Seminarii Neotestamentici Upsaliensis 20; Lund: Gleerup 1954. ${ }^{2} 1968$ ).

Strauss, D.F., The Life of Jesus Critically Examined, Translated from the Fourth German Edition (London: Swan Sonneschein - New York, NY: Macmillan ${ }^{2} 1892$ ).

Strecker, G., Der Weg der Gerechtigkeit. Untersuchung zur Theologie des Matthäus (Forschungen zur Religion und Literatur des Alten und Neuen Testaments 82; Göttingen: Vandenhoeck \& Ruprecht 1962).

Styler, G.M., „The Priority of Mark”, The Two-Source Hypothesis. A Critical Appraisal (red. A.J. Bellinzoni) (Macon, GA: Mercer University Press 1985) 63-75.

Thomas Aquinas, Doctoris Angelici divi Thomae Aquinatis sacri ordinis F.F. Praedicatorum opera omnia [...]. XIX. Commentarium super Matthaeum (Parisiis: apud Ludovicum Vivès 1876).

Waltke, B.K. - O'Connor, M., An Introduction to Biblical Hebrew Syntax (Winona Lake, IN: Eisenbrauns 1990).

Way, K.C., „Donkey Domain: Zechariah 9:9 and Lexical Semantics”, Journal of Biblical Literature 129 (2010) 105-114.

Way, K.C., Donkeys in the Biblical World. Ceremony and Symbol (History, Archaeology, and Culture of the Levant 2; Winona Lake, IN: Eisenbrauns 2011).

Weren, W., „Jesus' Entry into Jerusalem. Mt 21,1-17 in the Light of the Hebrew Bible and the Septuagint", The Scriptures in the Gospels (red. C.M. Tuckett) (Bibliotheca Ephemeridum Theologicarum Lovaniensium 131; Leuven: Leuven University Press - Peeters 1997) 117-141.

Whitby, D., „A Commentary on the Gospels and Epistles of the New Testament”, A Critical Commentary and Paraphrase on the Old and New Testament and the Apocrypha (London: Thomas Tegg 1842) IV, 33-205. 
Winterbothom, R., „The Ass and the Ass's Colt: St. Matthew xxi. 1-7”, Expository Times 28 (1917) 380-381.

Witherington, B., Matthew (Smith \& Helwys Bible Commentary; Macon, GA: Smith \& Helwys 2006).

Wolters, A., Zechariah (Historical Commentary on the Old Testament; Leuven - Paris - Walpole, MA: Peeters 2014). 